Prepared in cooperation with the North Dakota Department of Health and the North Dakota State Water Commission

\title{
Modeled Sulfate Concentrations in North Dakota Streams, 1993-2008, Based on Spatial Basin Characteristics
}

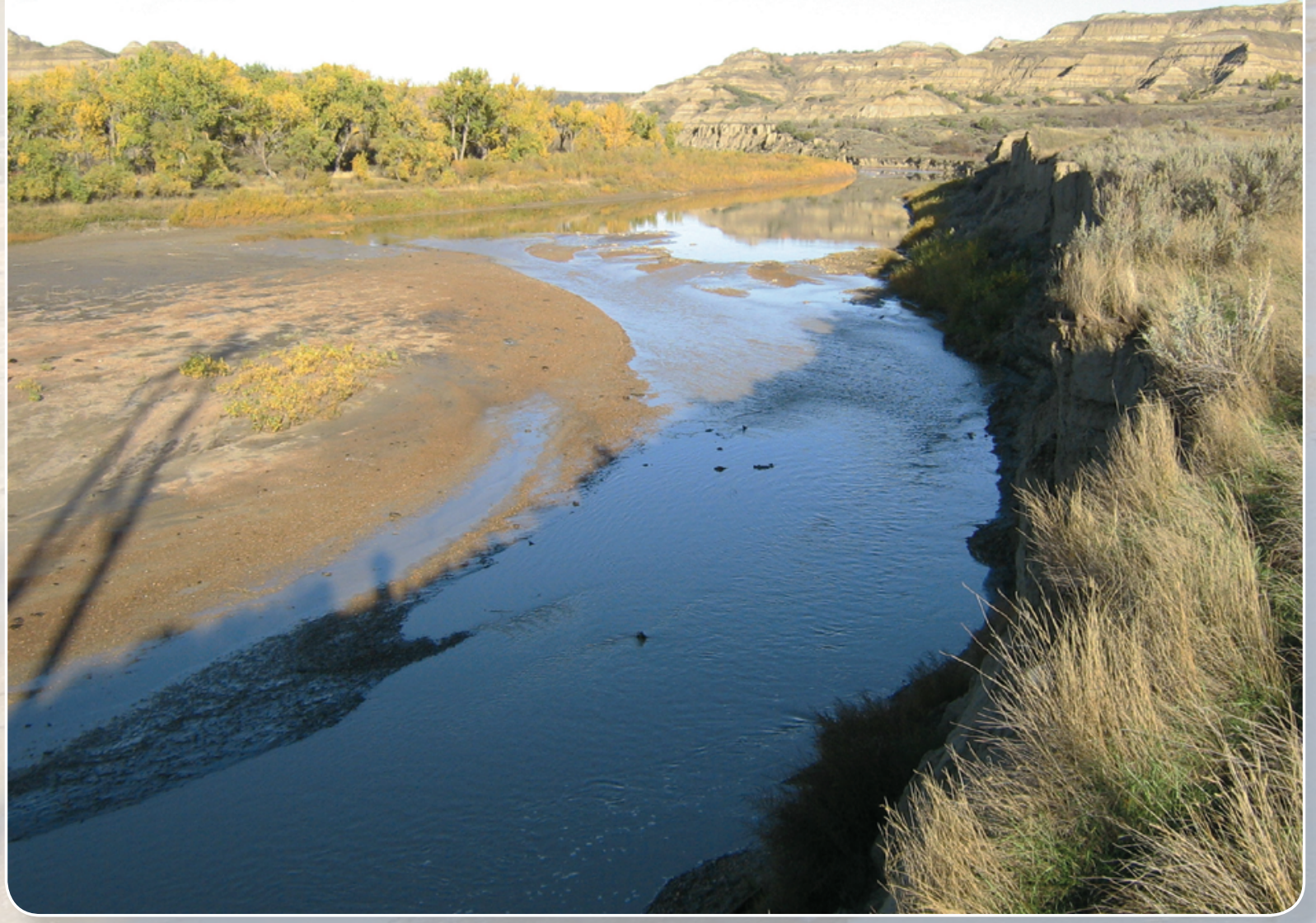

Scientific Investigations Report 2014-5092 
Cover photograph: Little Missouri River at Medora, North Dakota

(Photograph by Dennis R. Rosenkranz, U.S. Geological Survey, 2008). 


\section{Modeled Sulfate Concentrations in North Dakota Streams, 1993-2008, Based on Spatial Basin Characteristics}

By Joel M. Galloway and Aldo V. Vecchia

Prepared in cooperation with the North Dakota Department of Health and the North Dakota State Water Commission

Scientific Investigations Report 2014-5092 


\title{
U.S. Department of the Interior SALLY JEWELL, Secretary
}

\section{U.S. Geological Survey Suzette M. Kimball, Acting Director}

\author{
U.S. Geological Survey, Reston, Virginia: 2014
}

For more information on the USGS — the Federal source for science about the Earth, its natural and living resources, natural hazards, and the environment, visit http://www.usgs.gov or call 1-888-ASK-USGS.

For an overview of USGS information products, including maps, imagery, and publications, visit http://www.usgs.gov/pubprod

To order this and other USGS information products, visit http://store.usgs.gov

Any use of trade, firm, or product names is for descriptive purposes only and does not imply endorsement by the U.S. Government.

Although this information product, for the most part, is in the public domain, it also may contain copyrighted materials as noted in the text. Permission to reproduce copyrighted items must be secured from the copyright owner.

Suggested citation:

Galloway, J.M., and Vecchia, A.V., 2014, Modeled sulfate concentrations in North Dakota streams, 1993-2008, based on spatial basin characteristics: U.S. Geological Survey Scientific Investigations Report 2014-5092, 22 p., http:// dx.doi.org/10.3133/sir20145092.

ISSN 2328-0328 (online 


\section{Contents}

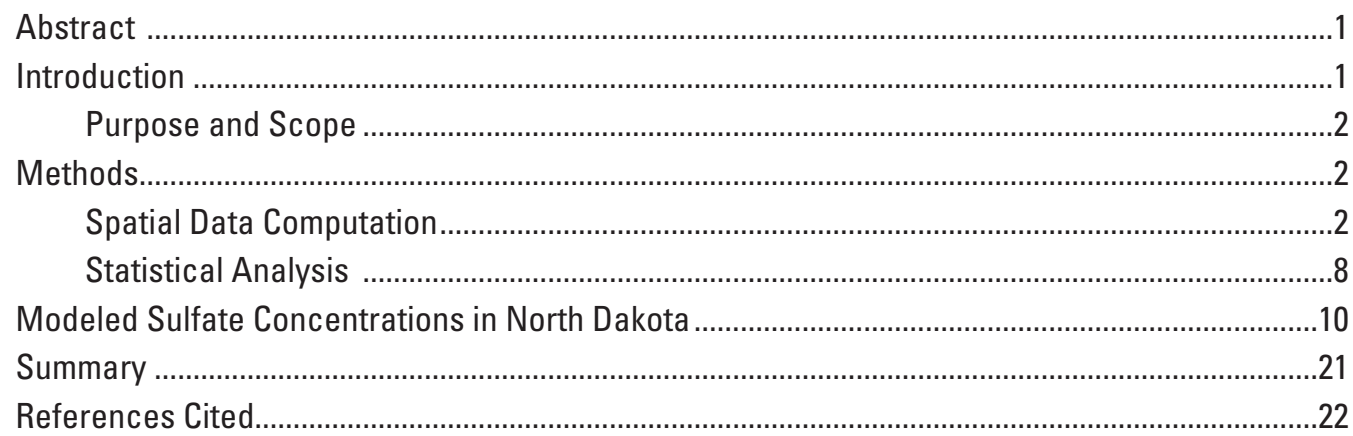

\section{Figures}

1. Map showing locations of selected sites in North Dakota ...............................................6

2. Map showing contributing basins for selected sites in North Dakota ...............................7

3. Graphs showing comparison of sulfate concentrations and time of year for selected sites for 1993-2008...............................................................................................................

4. Graph showing relative percent difference between sulfate concentration percentiles for High-Low Sampling Program (HLSP) samples and maximum seasonal sulfate concentration for sites with sufficient samples to estimate maximum seasonal concentration.

5. Maps showing mean annual precipitation (1981-2010), mean percent soil clay content, mean percent saturation overland flow, and modeled maximum seasonal sulfate concentrations for 12-digit hydrologic units in North Dakota and parts of surrounding states.

6. Graph showing comparison of modeled to estimated maximum seasonal sulfate concentrations for selected sites in North Dakota

7. Graphs showing comparison of sulfate concentration residuals to modeled concentrations and basin characteristics for selected sites in North Dakota

8. Map showing modeled sulfate concentrations for 12-digit hydrologic units in North Dakota and parts of surrounding states

9. Maps showing modeled sulfate concentrations for North Dakota and parts of surrounding states

\section{Tables}

1. Selected stream sites and sulfate statistics for North Dakota from 1993 through 2008

2. Basin characteristics, and estimated and modeled maximum seasonal sulfate concentration for selected sites in North Dakota. 


\section{Conversion Factors}

\begin{tabular}{lcl}
\hline \multicolumn{1}{c}{ Multiply } & By & \multicolumn{1}{c}{ To obtain } \\
\hline millimeter (mm) & 0.03937 & inch (in.) \\
meter (m) & 3.281 & foot (ft) \\
kilometer $(\mathrm{km})$ & 0.6214 & mile (mi) \\
square kilometer $\left(\mathrm{km}^{2}\right)$ & 0.3861 & square mile (mi $\left.{ }^{2}\right)$ \\
liter (L) & 33.82 & ounce, fluid (fl. oz) \\
liter (L) & 2.113 & pint (pt) \\
liter (L) & 1.057 & quart (qt) \\
liter (L) & 0.2642 & gallon (gal) \\
cubic meter $\left(\mathrm{m}^{3}\right)$ & 264.2 & gallon (gal) \\
cubic meter $\left(\mathrm{m}^{3}\right)$ & 0.0002642 & million gallons (Mgal) \\
liter (L) & 61.02 & cubic inch (in $\left.{ }^{3}\right)$ \\
\hline
\end{tabular}

Vertical coordinate information is referenced to North American Vertical Datum of 1988 (NAVD 88).

Horizontal coordinate information is referenced North American Datum of 1983 (NAD 83).

Altitude, as used in this report, refers to distance above the vertical datum.

Concentrations of chemical constituents in water are given in milligrams per liter ( $\mathrm{mg} / \mathrm{L})$.

\section{Abbreviations}

$\begin{array}{ll}\text { DEM } & \text { digital elevation model } \\ \text { GIS } & \text { Geographic Information System } \\ \text { HLSP } & \text { High-Low Flow Sampling Program } \\ \text { HU } & \text { hydrologic unit } \\ \text { LANDSAT } & \text { Land Remote Sensing Satellite images } \\ \text { MAP } & \text { mean annual precipitation } \\ \text { NDDH } & \text { North Dakota Department of Health } \\ \text { NDSWC } & \text { North Dakota State Water Commission } \\ \text { PRISM } & \text { Parameterization-Elevation Regressions on Independent Slopes Model } \\ \text { SCC } & \text { mean percent soil clay content } \\ \text { SOF } & \text { mean percent saturation overland flow } \\ \text { STATSGO } & \text { State Soil Geographic dataset } \\ \text { USGS } & \text { U.S. Geological Survey }\end{array}$




\title{
Modeled Sulfate Concentrations in North Dakota Streams, 1993-2008, Based on Spatial Basin Characteristics
}

\author{
By Joel M. Galloway and Aldo V. Vecchia
}

\section{Abstract}

Sulfate concentration data collected from North Dakota streams during recent (1993-2008) years indicates generally higher sulfate concentrations across much of the State compared to concentrations during earlier years. The higher sulfate concentrations have been attributed in other studies to wetter climatic conditions, associated increases in contributing drainage areas, and rising water tables. The State's current (2013) stream classification system, which includes a standard for 30-day average sulfate concentration, is based on earlier data and thus may not reflect natural conditions for more recent years. The U.S. Geological Survey, in cooperation with the North Dakota Department of Health and the North Dakota State Water Commission, completed a study to evaluate the relation of maximum seasonal (30-day moving average) sulfate concentrations during 1993-2008 to characteristics of the contributing basins to model expected naturally-occurring sulfate concentrations in North Dakota streams.

Sulfate concentration data for 75 stream sampling sites in North Dakota were analyzed for this study. A spatial analysis was conducted with digital data using a Geographic Information System to obtain selected basin characteristics, which were in turn used as explanatory variables in a regression analysis to model the maximum seasonal (30-day moving average) sulfate concentration. Characteristics used in the regression analysis included mean annual precipitation, mean percent soil clay content, and mean percent saturation overland flow.

Modeled sulfate concentrations generally were highest (greater than 750 milligrams per liter) in basins in western North Dakota and lowest (less than 250 milligrams per liter) in basins in the upper Sheyenne River and upper James River. Area-weighted means for the basin characteristics also were computed for 10-digit and 8-digit hydrologic units for streams in North Dakota and modeled sulfate concentrations were computed from the characteristics. The resulting distribution of modeled sulfate concentrations was similar to the distribution of estimates for the 12-digit hydrologic units, but less variable because the basin characteristics were averaged over larger areas.

\section{Introduction}

Soils across North Dakota have naturally high sulfur content that readily oxidizes to highly soluble sulfate ions (Franzen, 2007). Therefore, sulfate concentrations in North Dakota streams tend to be relatively high. North Dakota waterquality standards, specifically for sulfate, are intended for the protection of municipal drinking water supplies and aquatic life (North Dakota Department of Health, 2010). The sulfate standards are 250 milligrams per liter $(\mathrm{mg} / \mathrm{L})$ (expressed as a 30-day arithmetic average) for Class I streams and $450 \mathrm{mg} / \mathrm{L}$ (expressed as a 30-day arithmetic average) for Class IA and II streams. The sulfate standard for all Class III streams in North Dakota, as well as the Sheyenne River from its headwaters to 0.1 mile downstream from Baldhill Dam (located at site 34 on fig. 1), is $750 \mathrm{mg} / \mathrm{L}$ (expressed as a 30-day arithmetic average). The standards for Class I, IA, and II streams are intended for the protection of drinking water use, whereas the $750 \mathrm{mg} / \mathrm{L}$ sulfate standard is intended to be protective of aquatic life (North Dakota Department of Health, 2010).

Recent analyses of water-quality data collected from streams in North Dakota indicated trends of increasing sulfate concentrations across the State (Galloway and others, 2012; Vecchia, 2003; Vecchia, 2005). Water-quality analysis by the North Dakota Department of Health (NDDH) also indicated that the sulfate standards have been exceeded at a number of stream water-quality monitoring locations across the State, some by an order of magnitude (Michael Ell, North Dakota Department of Health, written commun., 2013). Previous studies (Vecchia, 2005; Schuh and Hove, 2006) have indicated that the increasing sulfate concentrations probably were caused by generally wetter conditions that resulted in increases in contributing drainage areas and water tables beginning about 1993. The increasing sulfate across the State has prompted questions about whether the State's current stream classification system still appropriately reflects natural conditions. Where natural conditions cause exceedances of the existing sulfate standards, the NDDH may consider changes to the classification status of certain streams to reflect the higher sulfate concentrations. 
The U.S. Geological Survey (USGS), in cooperation with the North Dakota Department of Health (NDDH) and the North Dakota State Water Commission (NDSWC), conducted a study to evaluate the relation of maximum seasonal (30-day moving average) sulfate concentrations at monitoring sites in North Dakota to characteristics of the contributing basins. Characteristics that can potentially mobilize sulfate from the soil were used to model the expected naturally-occurring sulfate concentrations in streams. These characteristics included runoff from precipitation, the presence of clay in soil (often associated with higher sulfate content; Franzen, 2007), and characteristics that reflect the interaction of the runoff water with soils in the contributing basins.

\section{Purpose and Scope}

The purpose of this report is to describe a regression analysis to provide modeled maximum seasonal (30-day moving average) sulfate concentrations for 1993-2008 in streams in North Dakota based on basin characteristics derived using spatial data on soil properties, runoff characteristics, and precipitation. Modeled sulfate concentrations will be used by the NDDH to determine if the existing classifications of streams in North Dakota are appropriate in light of the higher sulfate concentrations. Estimates of the maximum seasonal sulfate concentrations at selected sites used in the regression analyses were obtained using measured sulfate concentration data from Galloway and others (2012).

\section{Methods}

A regression model was developed from regression analysis to model maximum seasonal sulfate concentrations in basins across North Dakota from selected characteristics of the basins. Sites and associated sulfate concentration data are a subset of the sites and data presented in Galloway and others (2012). The period selected for analysis of sulfate concentrations was from 1993 through 2008. This period was selected to maximize the number of sites with a common period of record and to make the results representative of current conditions. Compared to earlier years, climatic conditions in North Dakota generally became wetter and more variable after 1993 (Hoerling and others, 2010; Vecchia, 2008), and thus streamflow and sulfate concentration data collected in the recent period are expected to better represent future conditions than streamflow and concentration data collected before 1993. Sites from Galloway and others (2012) that had at least 10 samples between 1993 and 2008 were used in the initial dataset for the regression analysis in this report. From the initial dataset, sites were further eliminated that had most of their basin located in Canada and that were located below major dams and may not reflect seasonal sulfate concentrations associated with characteristics of the upstream watersheds. Sites that may redundantly represent a large basin such as multiple sites on the Red
River of the North that did not have much variation in basin size were also removed (fig. 1). The final dataset used for the regression analysis included 75 sites (table 1; figs. 1 and 2). The site identification numbers in table 1 and figs. 1 and 2 are the same as the site numbers from Galloway and others (2012). The concentration data used for this analysis are based on samples collected by the North Dakota Department of Health, North Dakota State Water Commission, and U.S. Geological Survey and are described in more detail in Galloway and others (2012). This section describes the methods used for obtaining selected basin characteristics and the statistical methods used for developing relations between basin characteristics and sulfate concentrations at the selected sites.

\section{Spatial Data Computation}

A spatial analysis was conducted with digital data using a Geographic Information System (GIS) to obtain selected basin characteristics. Characteristics from several datasets were extracted for each 12-digit Hydrologic Unit (HU) (U.S Geological Survey and others, 2012) that encompassed streams in North Dakota (fig. 2). Characteristics extracted for each HU included the mean annual precipitation (MAP), mean percent soil clay content (SCC), and mean percent saturation overland flow (SOF). A much larger set of potential basin characteristics was considered for inclusion in the regression analysis, but exploratory analysis of the larger set using the stepwise procedure from the statistical package S-Plus (TIBCO Software Inc., 2010) with the "exhaustive" option to evaluate all possible subsets of explanatory variables and determine the subsets with the smallest mean-squared errors, indicated the three selected characteristics described in this section provided the best combination of explanatory variables.

Precipitation is an important variable for evaluating sulfate concentrations because basins with higher precipitation (especially snow that produces spring snowmelt runoff) can result in more dilution of shallow groundwater runoff and hence lower sulfate concentration compared to basins with less precipitation. The mean annual precipitation (MAP) from 1981 to 2010 was obtained from Parameter-Elevation Regressions on Independent Slopes Model (PRISM) data (PRISM Climate Group, 2012). The PRISM model is an analytical model that uses point data and an underlying grid such as a digital elevation model (DEM) or a 30-year climatological average to generate gridded estimates of monthly and annual precipitation and temperature (as well as other climatic parameters). The MAP was extracted for each 12-digit HU polygon associated with streams in North Dakota and some surrounding states from an 800-meter grid of mean annual precipitation. A mean value of the grid cells that were within each $\mathrm{HU}$ was computed for each $\mathrm{HU}$.

Soil clay content (SCC) is also an important variable for evaluating sulfate concentrations. North Dakota soils often contain gypsum (calcium carbonate) caused by the weathering of geologic materials (Franzen, 2012). Gypsum dissolved 


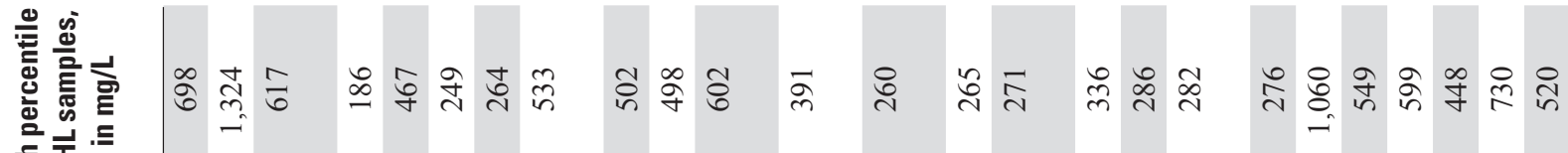
咅至

亮

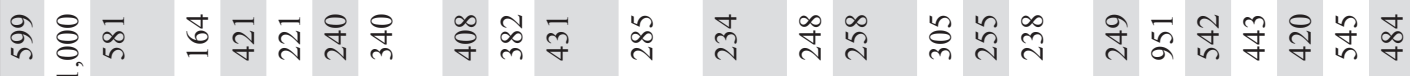
高空。

로.․․

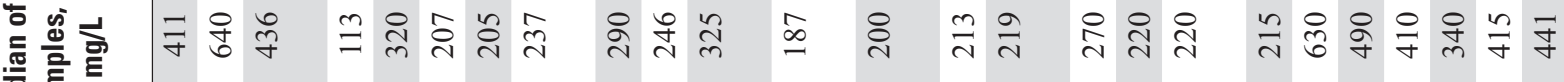
突

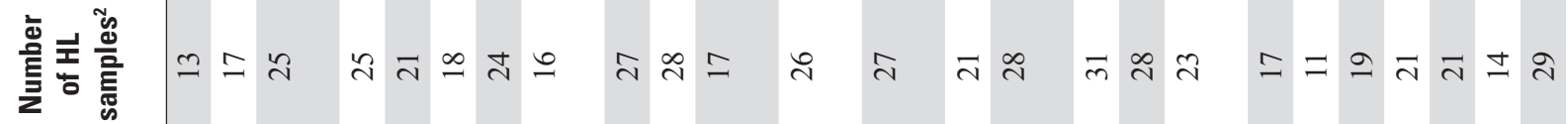

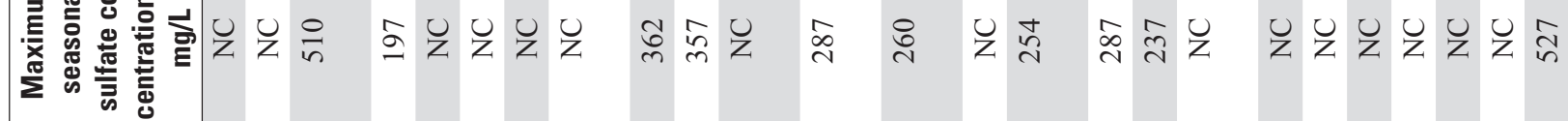

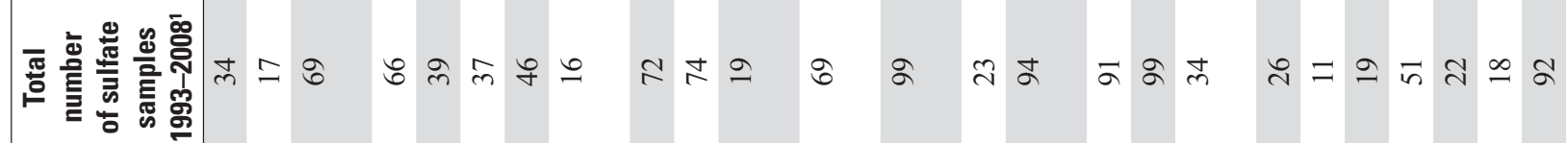

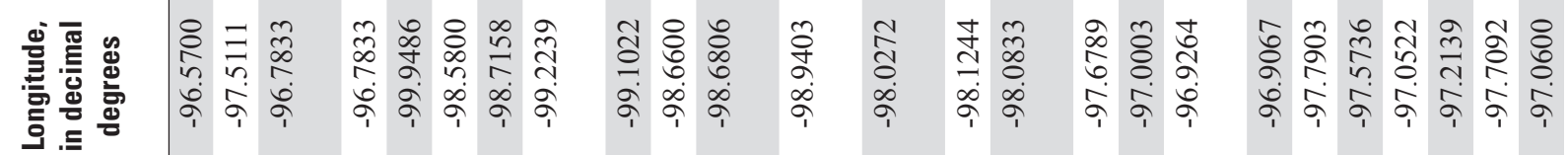

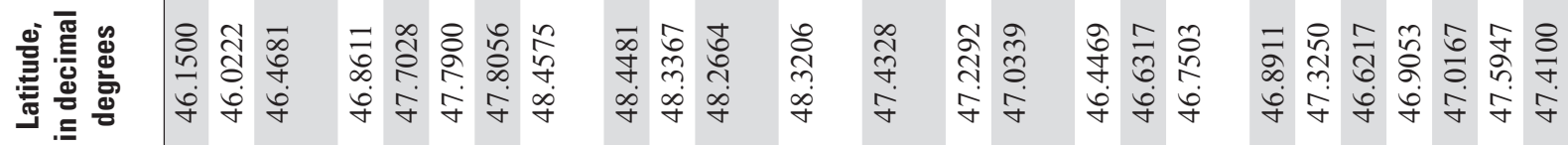

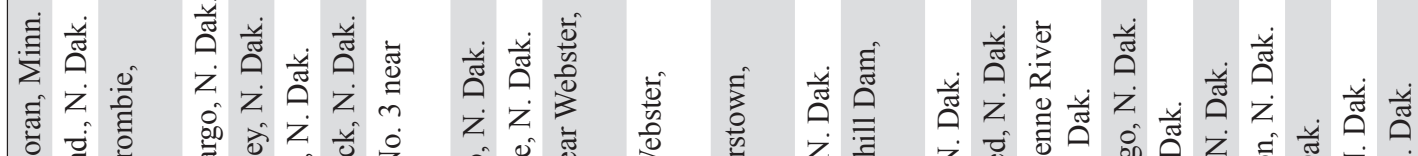

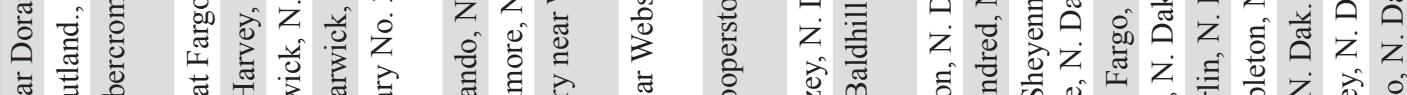

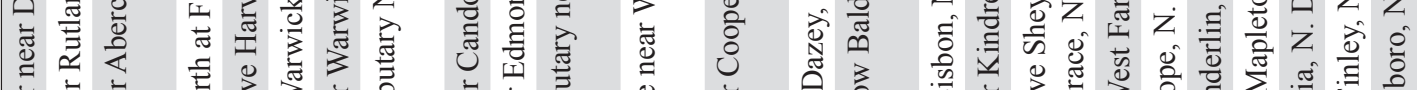

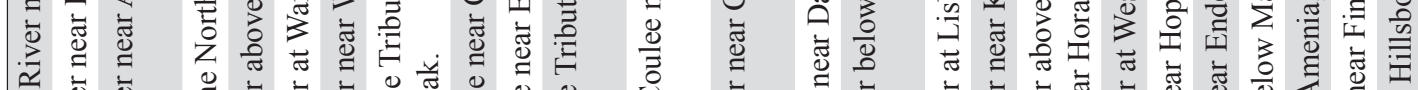

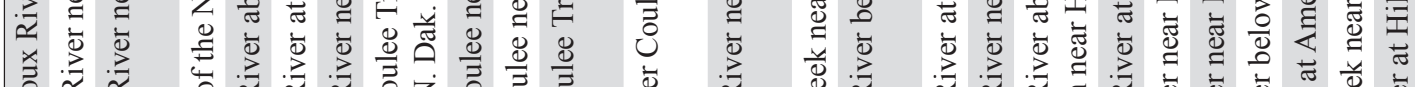

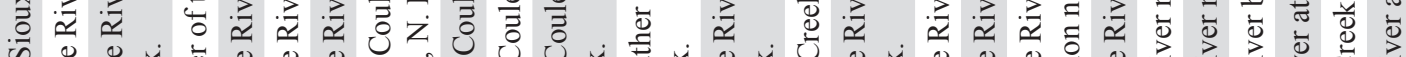
की

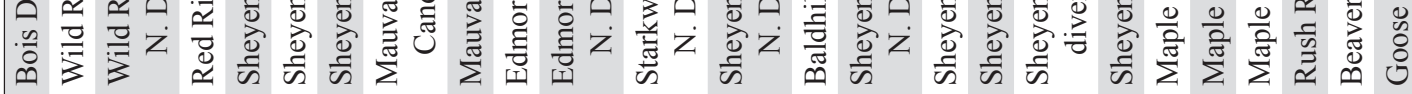

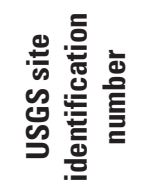

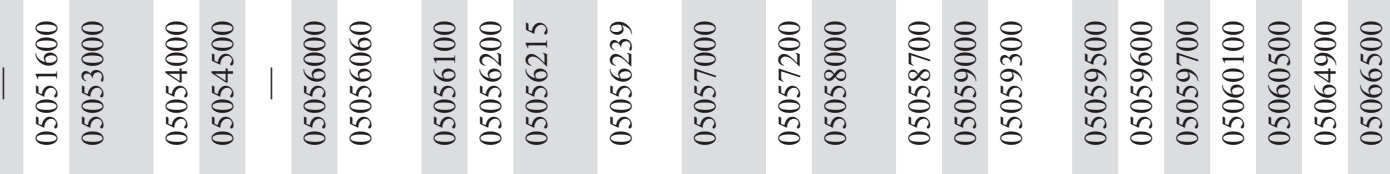

in

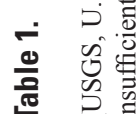

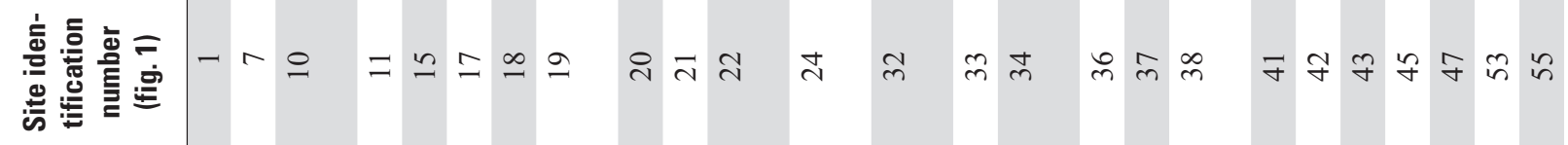




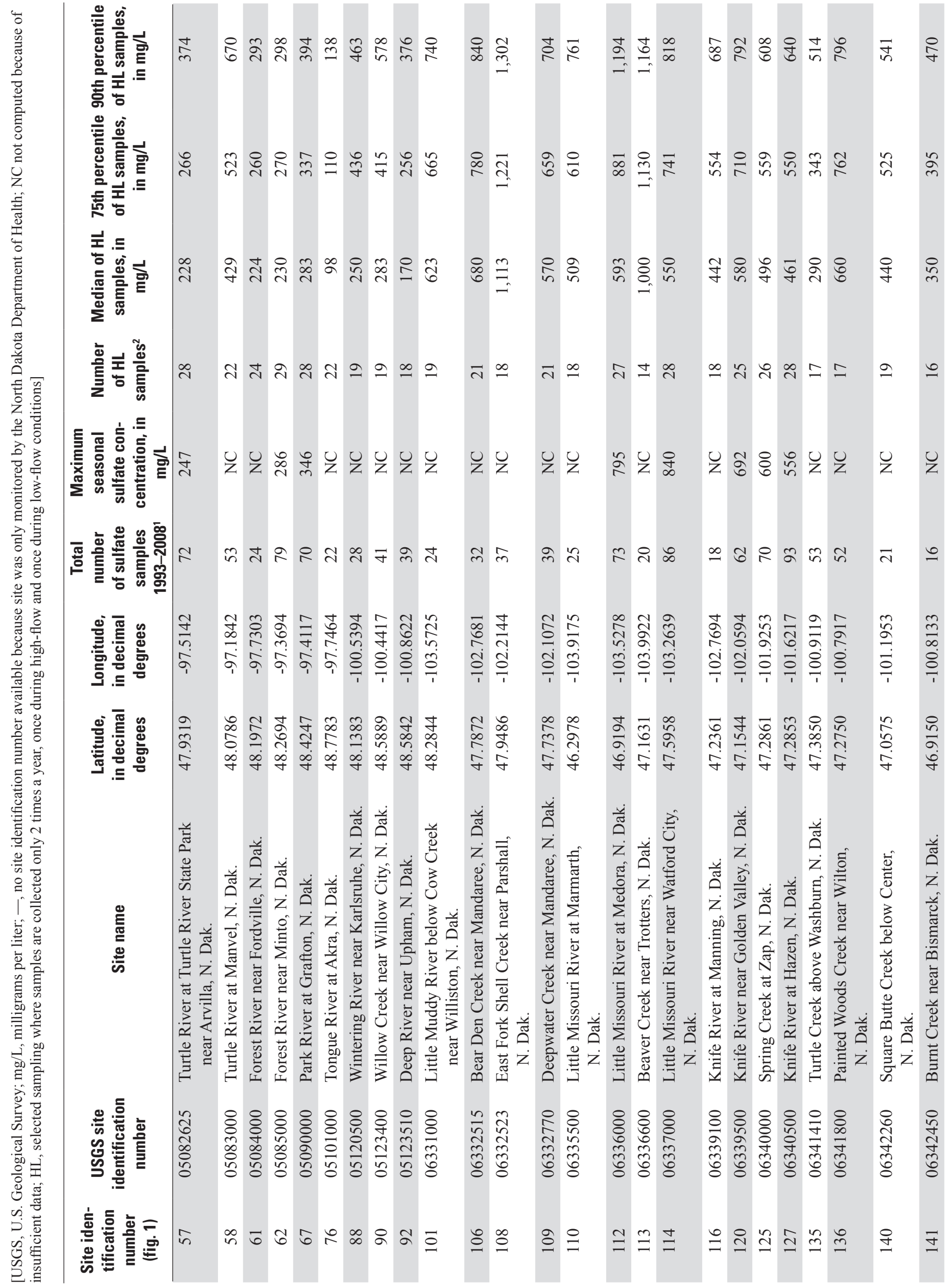




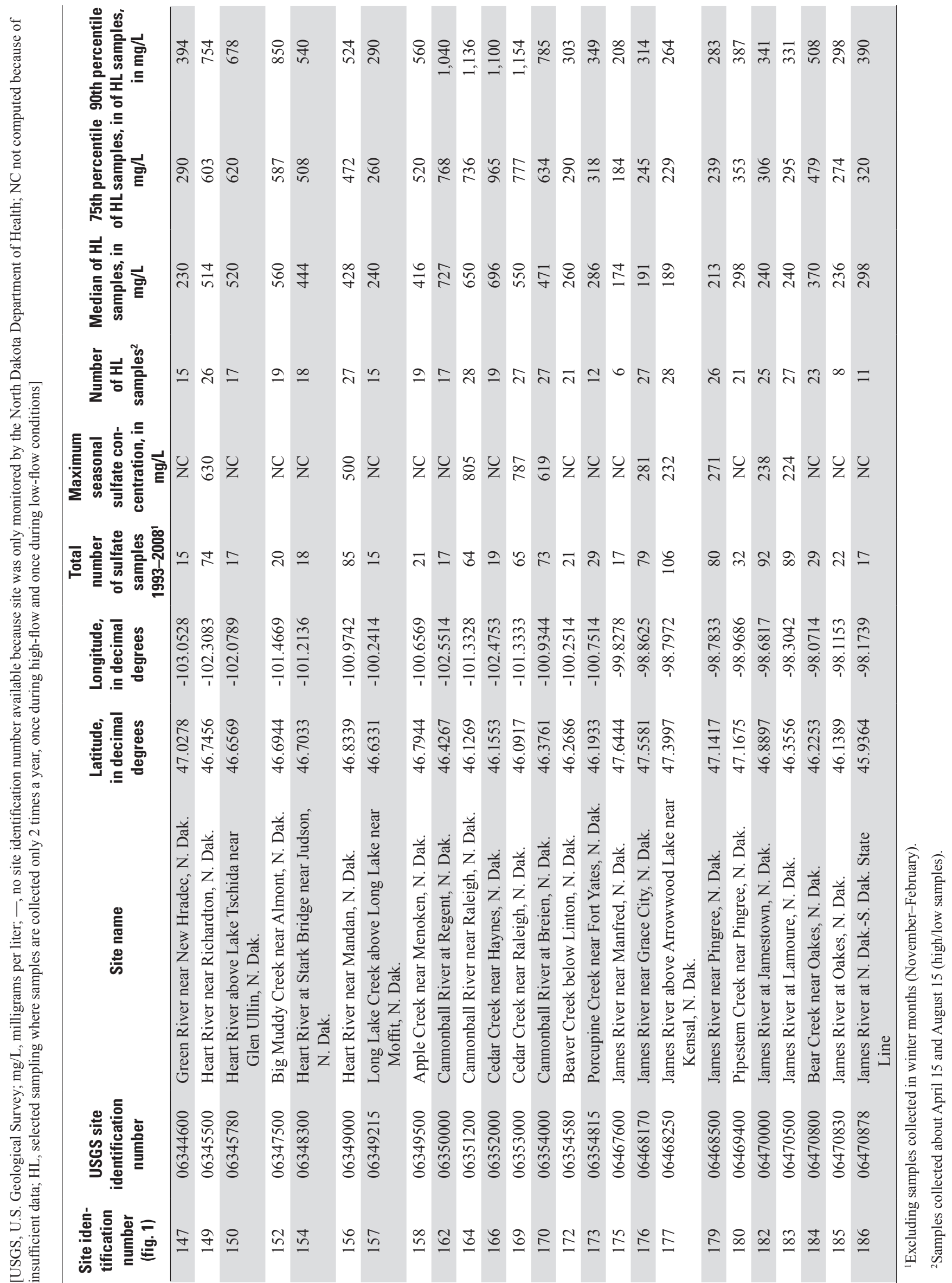




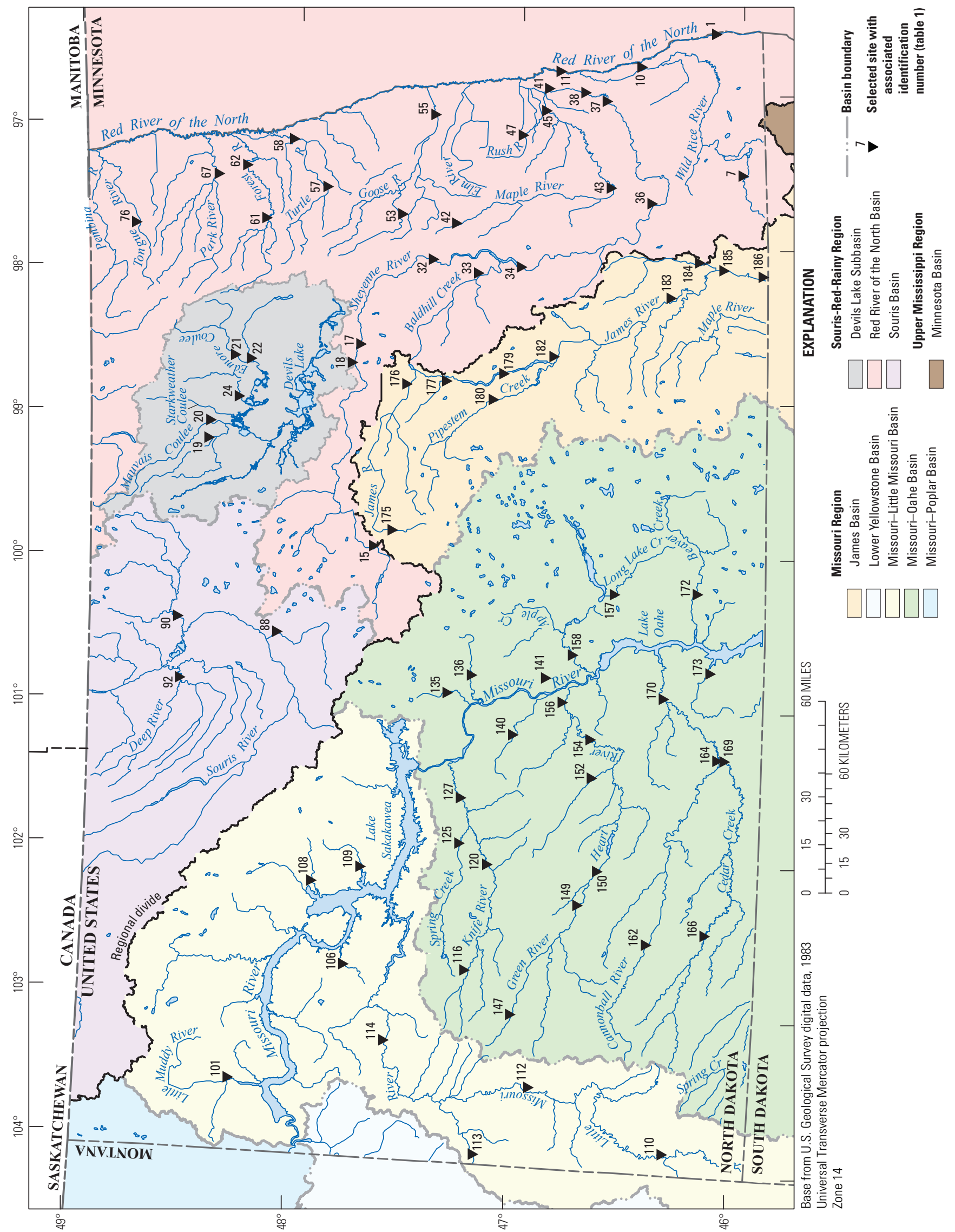

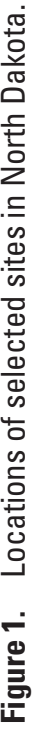




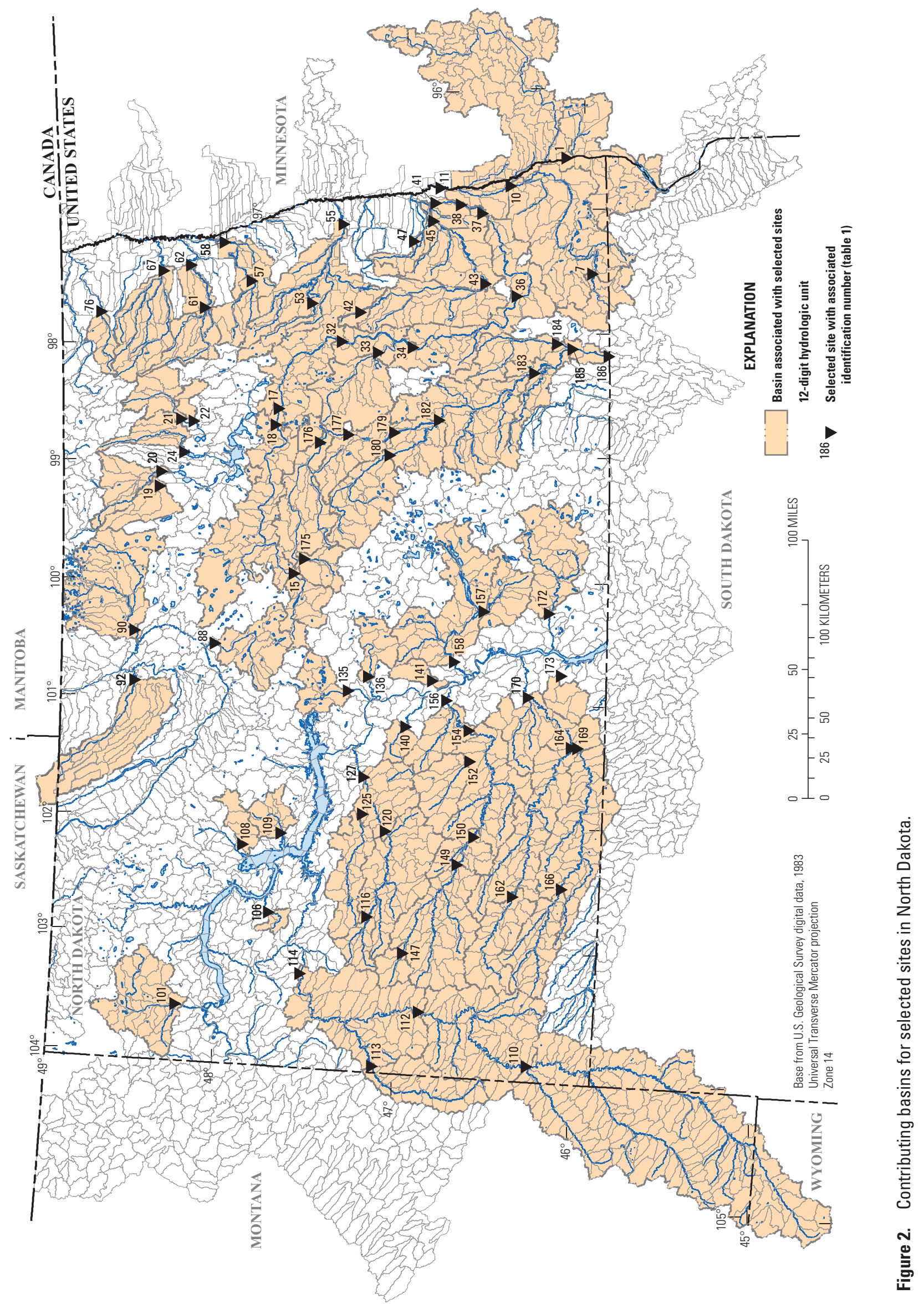


in water can return to the surface more readily in soils with greater clay content than in soils with greater sand content because of capillary rise, resulting in accumulation of gypsum near the soil surface (Franzen, 2012). In addition, soil clays will attract positively charged calcium ions and allow negatively charged sulfate ions to remain in solution (Rehm, 2002). The sulfate can then be washed off during rainfall events leading to potentially higher stream concentrations. The percent SCC was obtained from the U.S. General Soil Map (U.S. Department of Agriculture, 2006). The U.S. General Soil Map dataset consists of general soil association units developed by the National Cooperative Soil Survey and supersedes the State Soil Geographic (STATSGO) dataset published in 1994 (U.S. Department of Agriculture, 2006). The dataset was created by generalizing more detailed soil survey maps. Where more detailed soil survey maps were not available, data on geology, topography, vegetation, and climate were assembled together with Land Remote Sensing Satellite (LANDSAT) images (U.S. Department of Agriculture, 2006). The U.S. General Soil Map dataset consists of georeferenced vector digital data and tabular digital data. The soil map units are linked to attributes in the National Soil Information System database (U.S. Department of Agriculture, 2006), which give the proportionate extent of the component soils and their properties. The mean percent SCC (coded in the U.S. General Soil Map dataset as the representative value) was computed for each HU in GIS by using an area-weighted-mean value based on the area of each soil unit that was located within each HU. The percent SCC is described as "mineral particles less than 0.002 millimeter $(\mathrm{mm})$ in equivalent diameter as a weight percentage of the less than $2.0 \mathrm{~mm}$ fraction" (U.S. Department of Agriculture, 2006).

Saturation overland flow (SOF) is a measure of the amount of runoff that comes from shallow groundwater sources rather than from excess precipitation runoff. Therefore, runoff from basins with high SOF would be expected to have more contact with shallow soils and hence higher sulfate concentration than would runoff from basins with low SOF. The percent SOF was obtained from digital datasets described in Wolock (2003a and 2003b). The SOF was estimated for the conterminous United States using the watershed model TOPMODEL (Beven and Kirkby, 1979). TOPMODEL simulates the movement of water through a watershed from the time that it enters the watershed as precipitation to the time that it exits the watershed as streamflow. TOPMODEL predicts streamflow, estimates overland and subsurface flow, and estimates the depth to the water table. The SOF is calculated from the areal extent of the saturated land-surface area and the precipitation intensity. Subsurface flow is computed as a function of the maximum subsurface-flow rate (determined by topography and soil characteristics) and the watershed average depth to the water table. The watershed average depth to the water table is computed by water balance; that is, by tracking input (precipitation) and output (overland flow, subsurface flow, and evapotranspiration) (Wolock, 2003a and 2003b). The TOPMODEL was applied to a grid with a 5-by-5 kilometer cell size for the conterminous United States. The mean SOF was extracted from the grid for each 12-digit HU polygon associated with streams in North Dakota and some surrounding states.

For the regression analysis, a single value for each characteristic was needed for each site that had associated sulfate data. For each site, all of the 12-digit HUs upstream from the site were combined and an area-weighted mean based on the area of each 12-digit HU was computed for the MAP, mean percent SCC, and percent SOF for the basin upstream from the site. If a site was not located on a HU boundary, and located somewhere within the most downstream HU, the most downstream HU may or may not have been selected to include in the combined basin. For example, if a site was located closer to the upstream boundary of its most downstream 12-digit HU, the HU was not included. However, if a site was located closer to the downstream boundary of its most downstream HU, then the HU was included. Because the exact drainage area for each site was not delineated, the published drainage area for each site (U.S. Geological Survey, 2013) may not match exactly to the drainage area computed for the analysis in this report (fig. 2, table 2). Also, 12-digit HUs that were denoted in the GIS data file to be closed basins (basins that have no defined outflow) were not included in the accumulated basins, and may, therefore, create differences between the published drainage area and the computed drainage area.

\section{Statistical Analysis}

The sulfate standards for various stream classifications for North Dakota, as determined by the NDDH, are based on a 30-day average concentration (North Dakota Department of Health, 2010). However, the sulfate data used in this analysis consists of samples collected on discrete days and the number and timing of the concentration samples within each year varied widely among sites. This variability required different statistical analyses depending upon the number of samples at a site. As indicated earlier, the concentration data used for this analysis are based on samples collected by the NDDH, NDSWC, and USGS as part of various sampling programs described in more detail in Galloway and others (2012). For example, some of the sites given in table 1, such as site 11 (Red River of the North at Fargo, N.Dak.), were part of the NDDH Ambient Water-Quality Network (hereafter referred to as the ambient network) and were sampled eight times per year whereas other sites, such as site 7 (Wild Rice River near Rutland, N.Dak.), were part of the NDSWC High-Low Flow Sampling Program (HLSP) and were sampled twice per year during a high-flow period (usually in April) and a low-flow period (usually in August) (Galloway and others, 2012).

For sites with sufficient number of samples, the maximum 30-day moving average sulfate concentration, hereafter called the maximum seasonal sulfate concentration, was estimated in the following manner. First, winter (November through February) samples were excluded so that the 

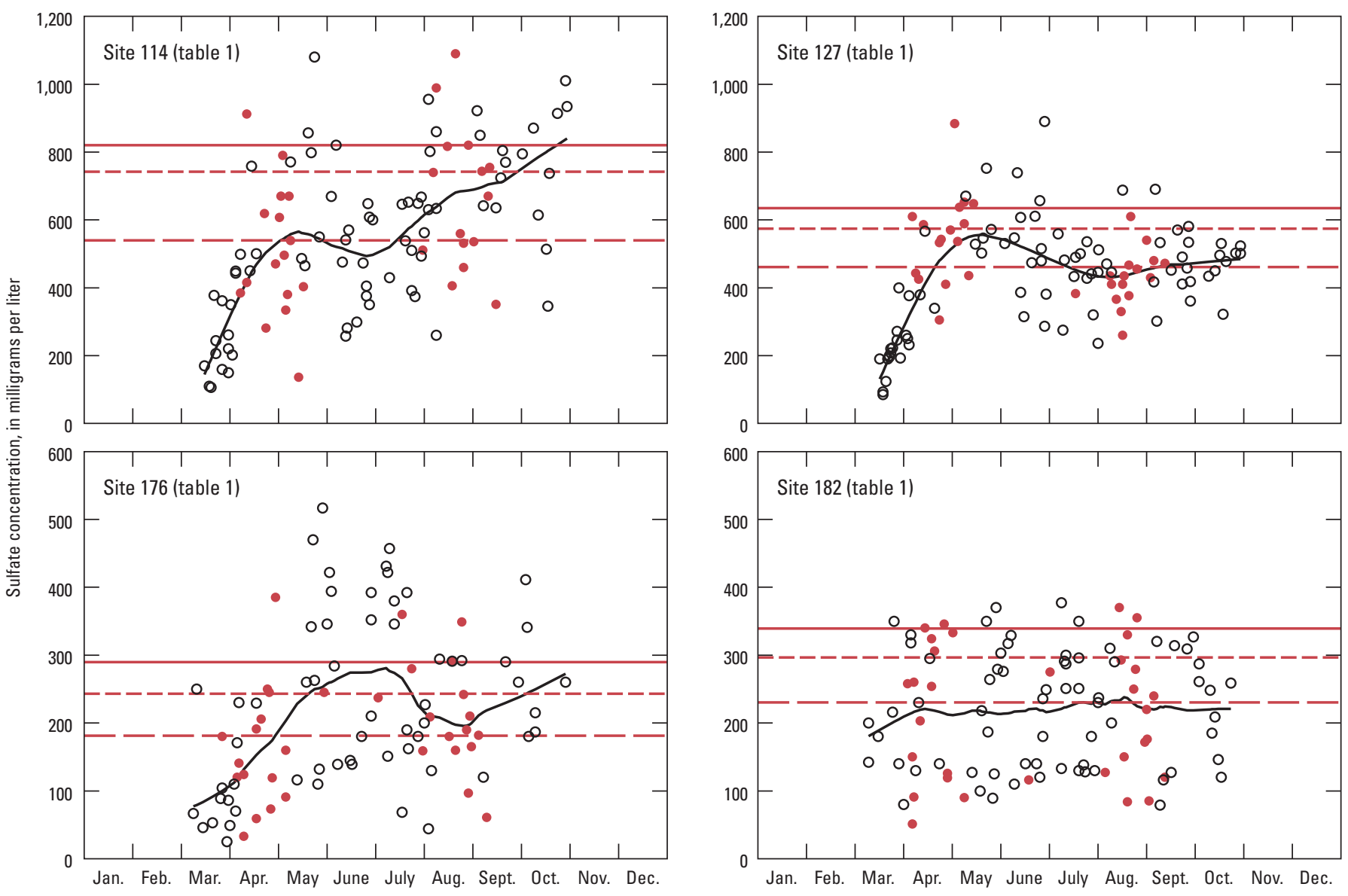

EXPLANATION

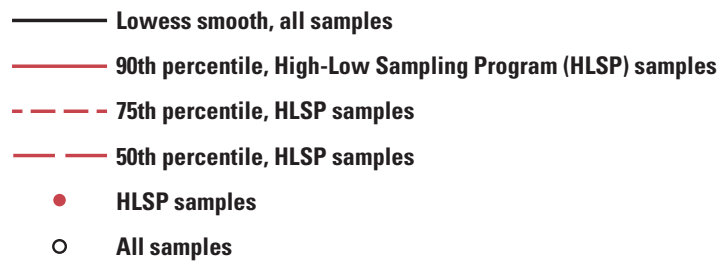

Figure 3. Comparison of sulfate concentrations and time of year for selected sites for 1993-2008.

concentrations represented open-water conditions. Then, if there were at least 60 samples during the remaining period (March through October), a continuous curve was fitted to the concentrations using the nonparametric smoothing procedure known as lowess (locally weighted scatterplot smoother) from the statistical package S-Plus (TIBCO Software Inc., 2010). The maximum value attained by the continuous curve was used as the estimate of the maximum seasonal sulfate concentration. Examples of this procedure for several sites are shown in figure 3. For site 114, the maximum seasonal concentration was about $800 \mathrm{mg} / \mathrm{L}$ and was attained in mid-October. For the remaining sites in figure 3 the maximum seasonal concentrations were about $556 \mathrm{mg} / \mathrm{L}$ (site 127, early May), about $281 \mathrm{mg} / \mathrm{L}$ (site 176, early July), and about $238 \mathrm{mg} / \mathrm{L}$ (site 182, mid-August). The maximum seasonal concentrations were determined in this manner for 28 of the sites that had at least 60 samples during March through October (table 1).

To allow for consistent estimation of the maximum seasonal concentration for all 75 sites, including the less frequently sampled HLSP sites, percentiles of the HLSP samples were computed and compared with the maximum seasonal concentrations for the sites with sufficient data to apply the previously described smoothing procedure. To simulate HLSP sampling, in each year, only the concentration samples nearest to April 15 (high flow) and August 15 (low flow) were selected. The selected HLSP samples for the example sites are shown in figure 3 as red points. The 50th, 75th, and 90th percentiles of the HLSP samples were compared with the estimated maximum seasonal concentrations described previously. For sites 114 and 176 (fig. 3), the 90th percentile of the HLSP 


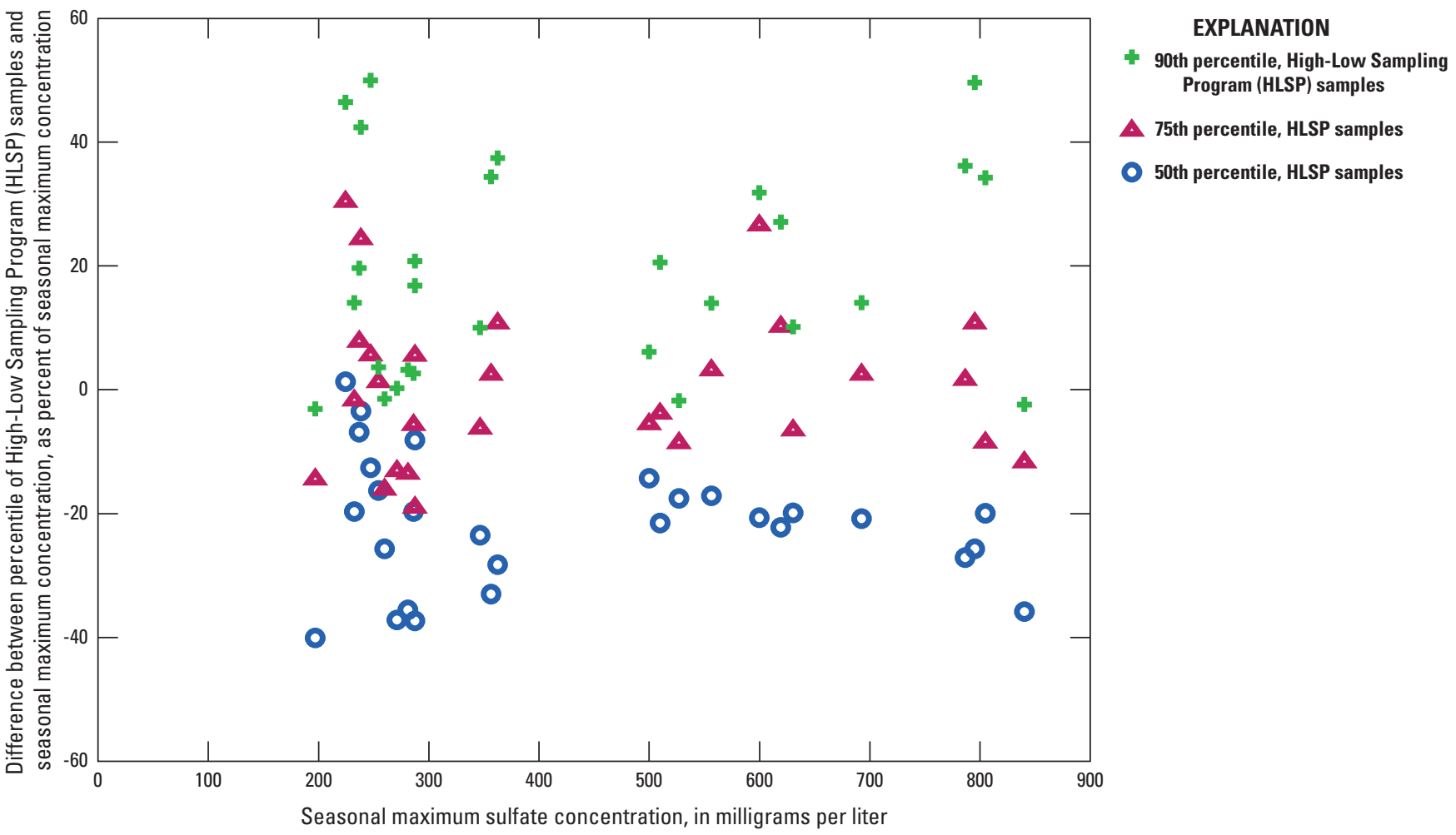

Figure 4. Relative percent difference between sulfate concentration percentiles for High-Low Sampling Program (HLSP) samples and maximum seasonal sulfate concentration for sites with sufficient samples to estimate maximum seasonal concentration.

samples was closest to the maximum seasonal concentration; for site 127 the 75 th percentile was closest; and for site 182 the 50th percentile was closest. The relative percent difference between the HLSP sample concentration percentiles and the maximum seasonal concentration (expressed as a percent of the maximum seasonal concentration) for each of the 28 sites for which the lowess smoothing procedure was applied is shown in figure 4 . For 21 of the 28 sites (including sites 114 and 127, fig. 3), the 75th percentile was within plus or minus 15 percent of the maximum seasonal concentration and for the remaining sites (including sites 176 and 182, fig. 3) the 75 th percentile was within 30 percent greater to 20 percent less than the maximum seasonal concentration. For the 90 th percentile, most (23 of 28) sites were between 0 and 60 percent greater than the maximum seasonal concentration and for the 50th percentile, most (27 of 28) sites were between 0 and 40 percent less than the maximum seasonal concentration. Based on this analysis, the 75th percentile of the selected samples used to simulate HLSP samples was selected as the estimate of the maximum seasonal concentration and was used in the regression analysis described in the "Modeled Sulfate Concentrations in North Dakota" section. The percentiles of the selected HLSP samples for all of the sites are given in table 1.

The modeled sulfate concentration described in the "Modeled Sulfate Concentrations in North Dakota" section was obtained using ordinary least-squares regression (Helsel and Hirsch, 1995) with the 75th percentile of the selected
HLSP samples as the dependent variable and the three spatial variables described previously (MAP, percent SCC, and percent SOF) as the explanatory variables.

\section{Modeled Sulfate Concentrations in North Dakota}

As described in the "Methods" section, MAP, percent SCC, and percent SOF were extracted for all of the 12-digit HUs for associated streams in North Dakota and surrounding States and weighted averages of these variables computed for the basins associated with the selected stream sites (table 2). The MAP (1981 to 2010) generally increased from west to east across North Dakota and ranged from 306 to $668 \mathrm{~mm}$ (fig. 5). The SCC was variable, although most of the lower values were distributed in a linear pattern running from the northwest to the south-central part of the state. The highest SCC values were distributed along the Red River of the North (eastern border of North Dakota) and in the far southern parts of the Little Missouri River Basin in Wyoming and in basins draining to Lake Oahe (Missouri River) in north-central South Dakota (figs. 1, 2, and 5). Values ranged from 0 to 55 percent SCC. The distribution of SOF generally had the lowest values in a horseshoe shape from north-central and northwestern North Dakota, extending south through eastern Montana and 

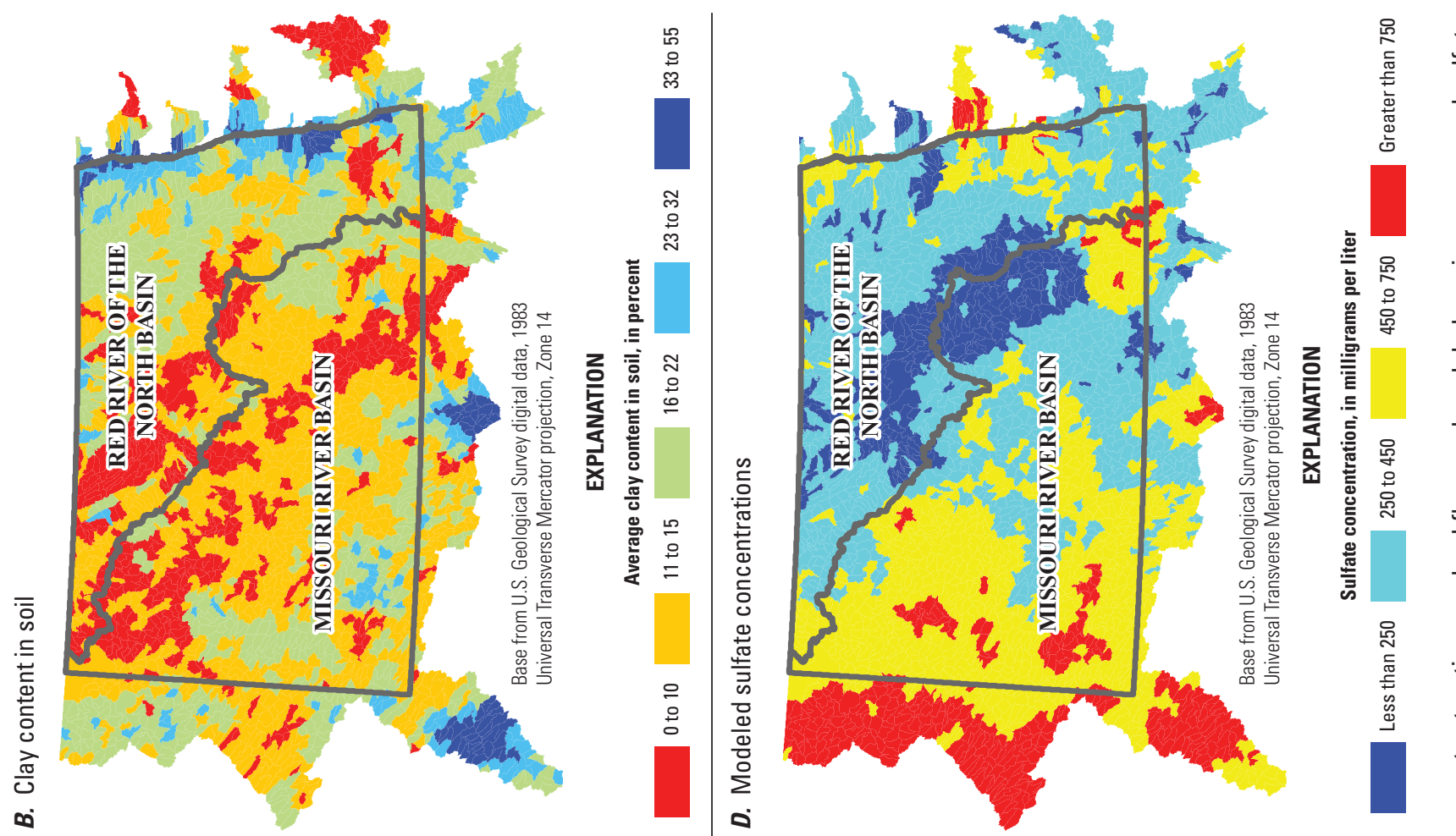

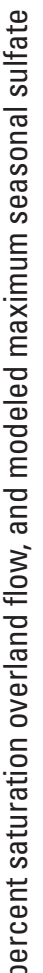
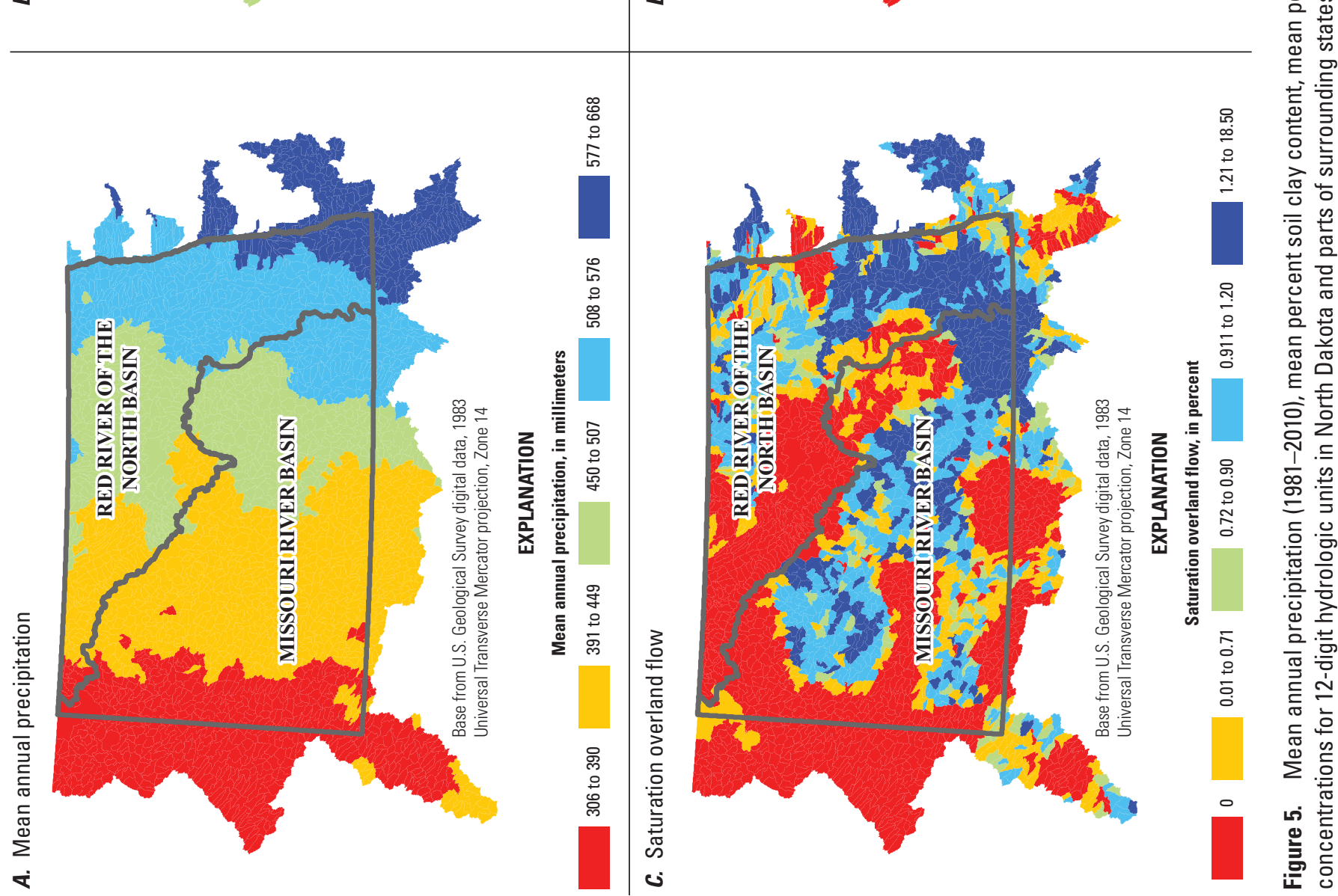


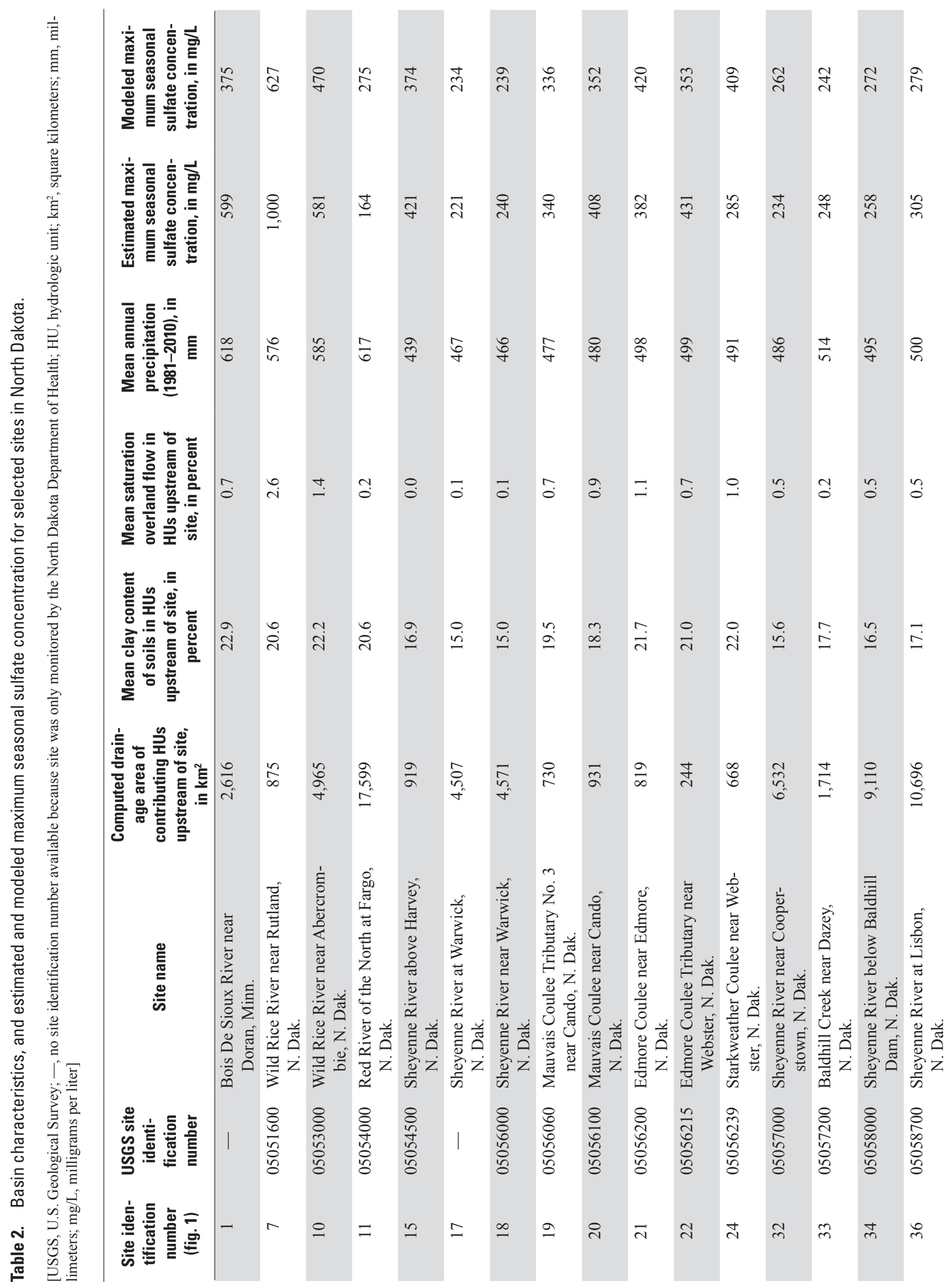




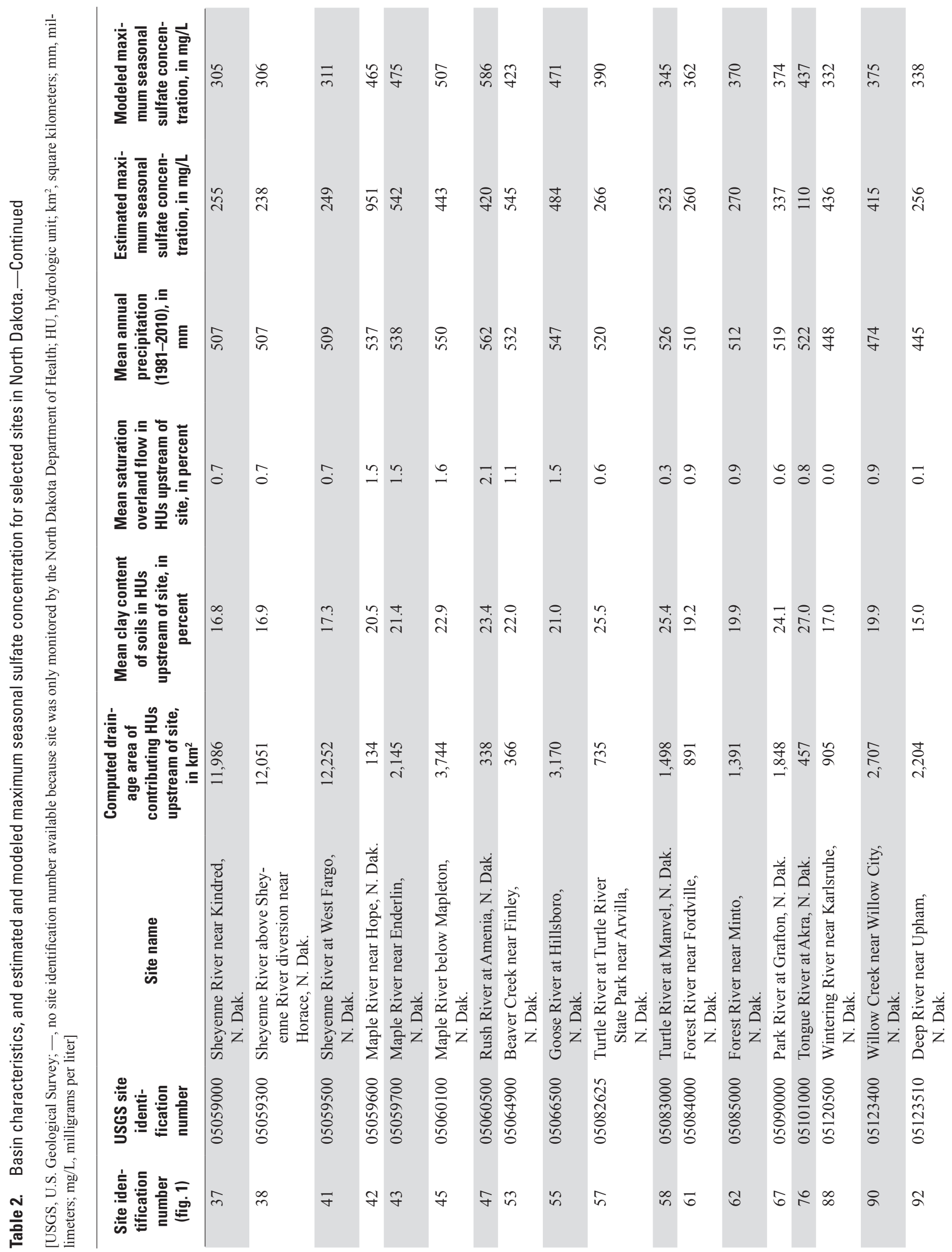




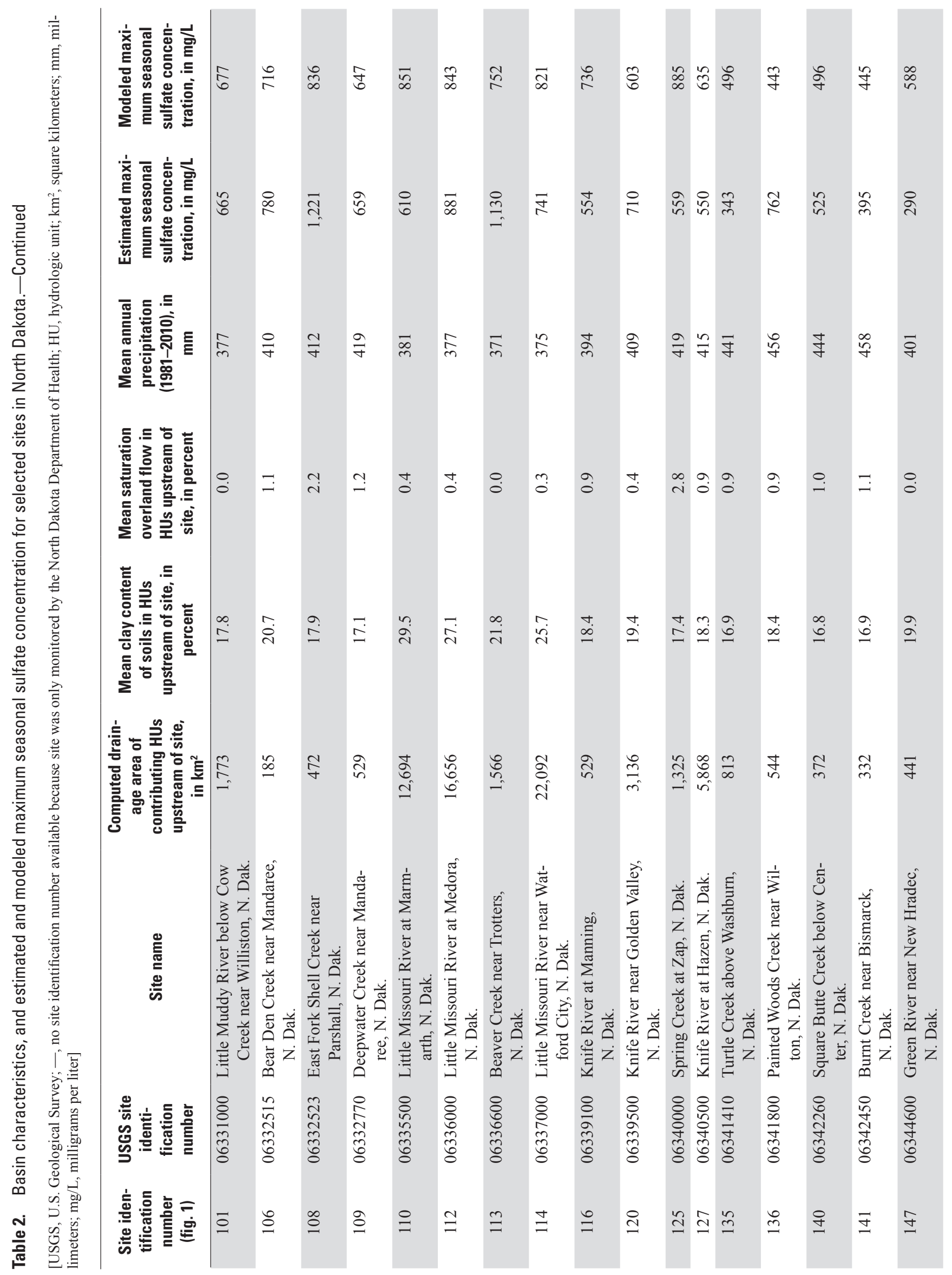




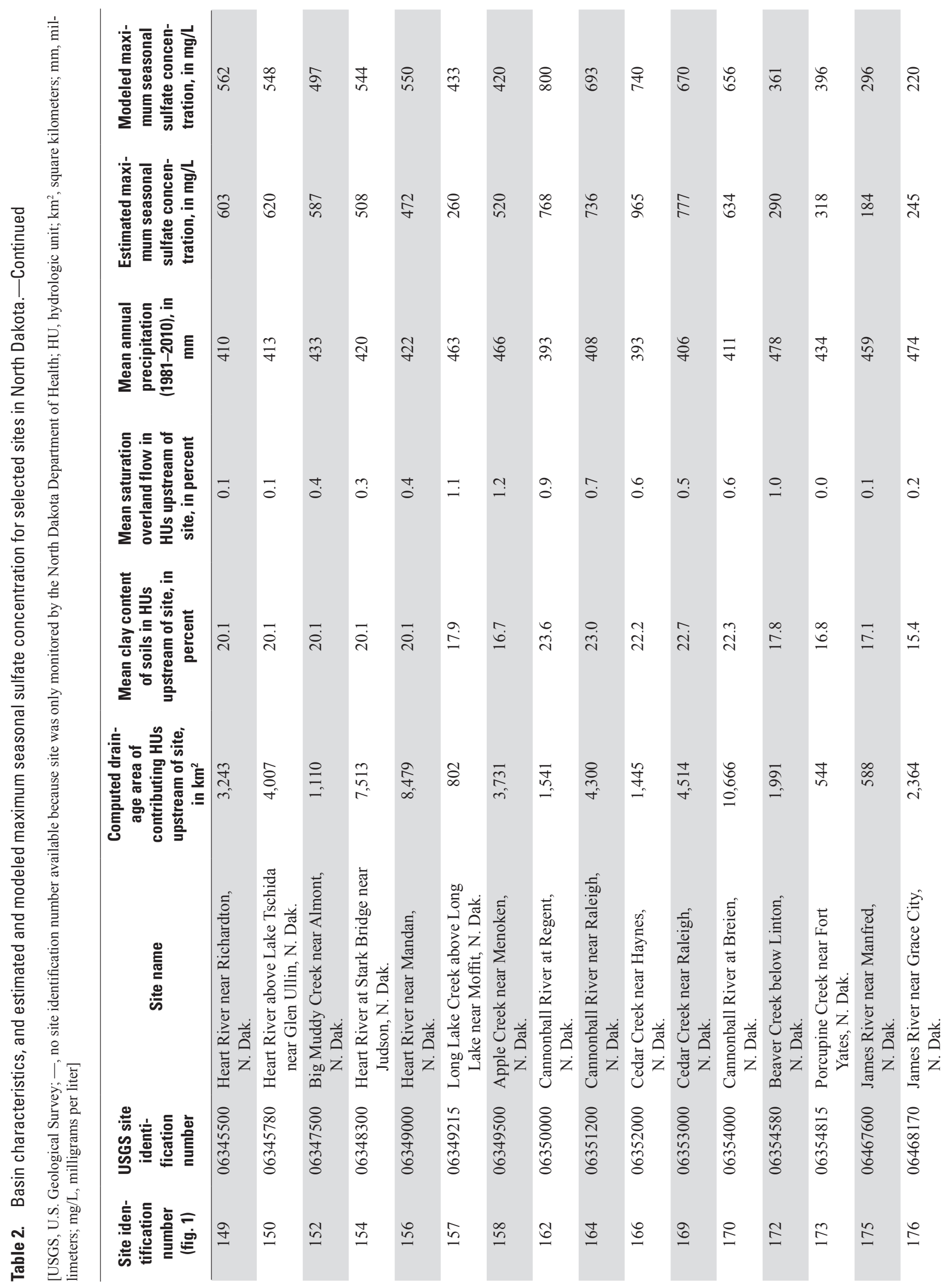




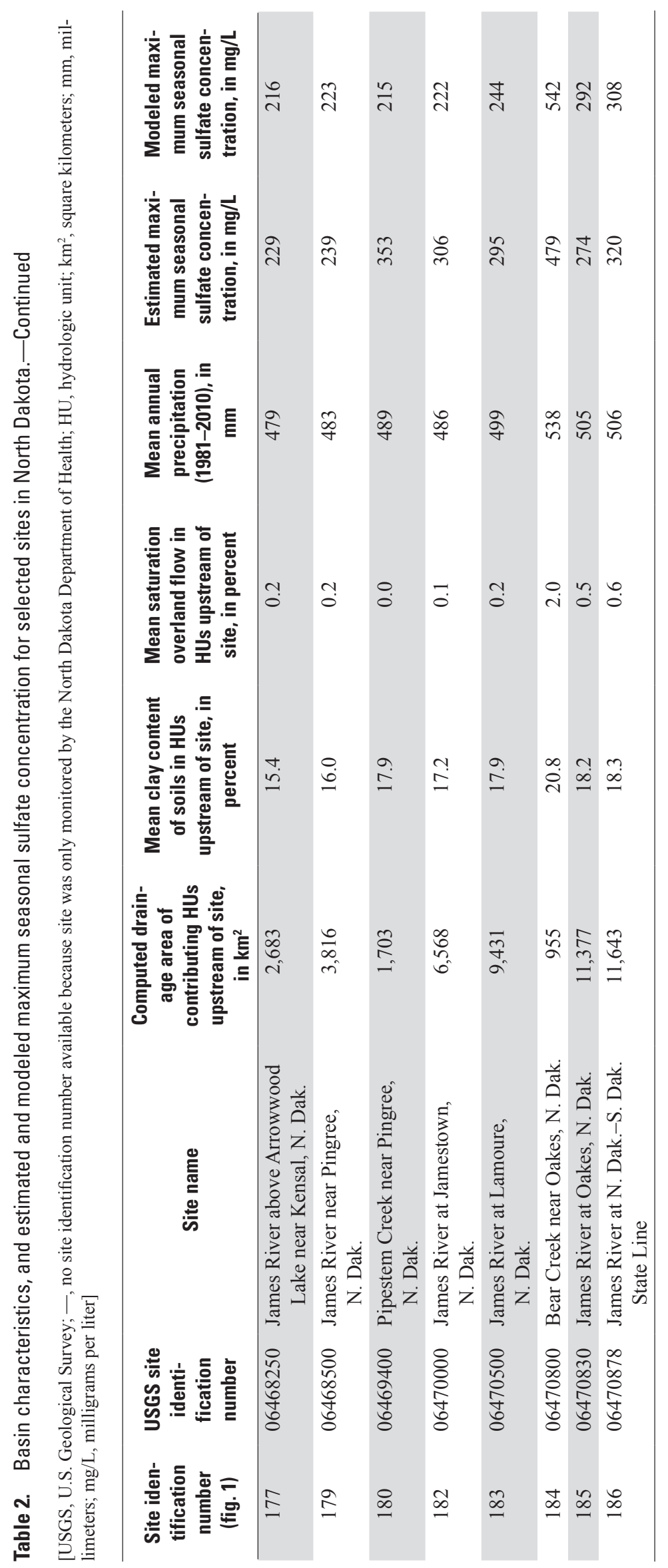


western North Dakota, and then extending into south-central North Dakota and north-central South Dakota. The highest values were in an inverted horseshoe shape from west-central to southeastern North Dakota and then extending north (fig. 5). Values of SOF ranged from 0 to 18.5 percent.

Ordinary least-squares regression was used to model estimated maximum seasonal sulfate concentration (represented by the $75^{\text {th }}$ percentile of the selected HLSP sample concentrations, as described in the "Methods" section) as a function of basin characteristics. The regression model was fitted using data for the 75 selected sites (table 2). The fitted regression model is given by

$$
\mathrm{MSC}_{B}=10.0+146.7 \mathrm{SOF}_{B}+11.4 \mathrm{SCC}_{B}+4.7\left[475-\mathrm{MAP}_{B}\right]_{+}
$$

where

MSC is the modeled sulfate concentration, in milligrams per liter;

SOF is the saturation overland flow, in percent;

$S C C$ is the soil clay content, in percent;

MAP is mean annual precipitation (1981-2010), in millimeters;

subscript $B \quad$ denotes the area-weighted average over HU's in a particular basin, and

$[\ldots]_{+} \quad$ is the quantity in brackets if the quantity is positive and zero otherwise.
Equation 1 indicates that MSC increases by $146.7 \mathrm{mg} / \mathrm{L}$ per 1-percent increase in SOF, $11.4 \mathrm{mg} / \mathrm{L}$ per 1-percent increase in SCC, and $4.7 \mathrm{mg} / \mathrm{L}$ per 1 millimeter $(\mathrm{mm})$ decrease in MAP for MAP below $475 \mathrm{~mm}$. In the wetter part of the State, where MAP is greater than $475 \mathrm{~mm}$ (covering about the eastern $1 / 3$ of the State, fig. 5), MSC does not vary with MAP. In the drier part of the State, precipitation is an important factor for MSC. Each of the coefficients for the explanatory variables was highly significant ( $p$-values less than 0.001 ) and the direction of the relations between MSC and each of the explanatory variables was consistent with physical expectations (see "Spatial Data Computation" section). The comparison of modeled to estimated sulfate concentrations for the selected sites are shown in figure 6 . The coefficient of determination was 80 percent and there was no obvious lack of model fit. Plots showing the comparison of residuals to the modeled concentrations and the explanatory variables (fig. 7) indicated an adequate model fit in all cases (random pattern of the residuals). Comparison of residuals to longitude and latitude of the centroid of the contributing basins for each site (fig. 7) did not indicate any obvious spatial patterns in the residuals.

Although equation 1 is expressed in terms of average values of each variable for a given basin, note that it is assumed to be valid for basins consisting of a single HU, and thus equation 1 can be used to compute modeled sulfate concentrations for each HU for mapping purposes (fig. 5).

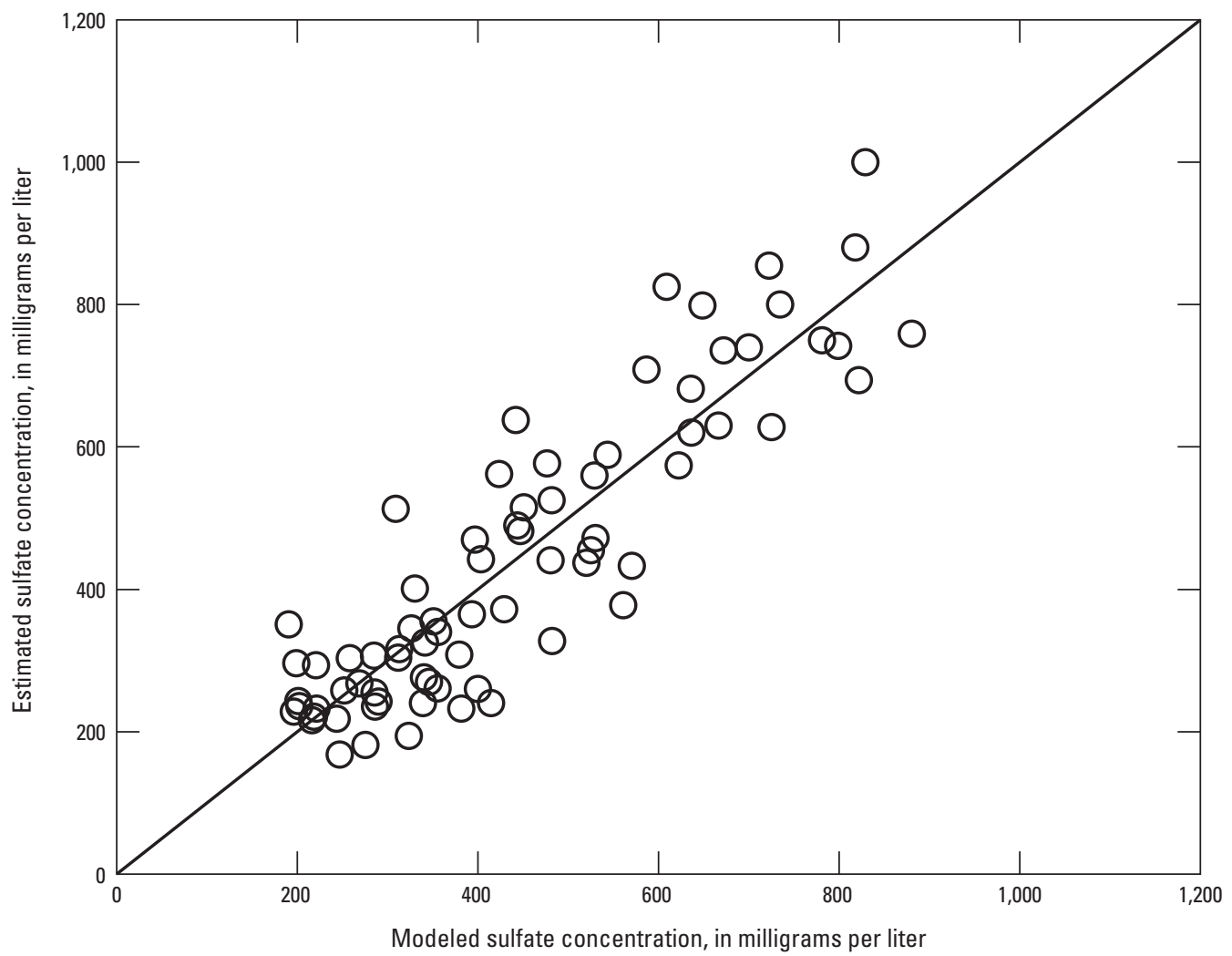

Figure 6. Comparison of modeled to estimated maximum seasonal sulfate concentrations for selected sites in North Dakota. 

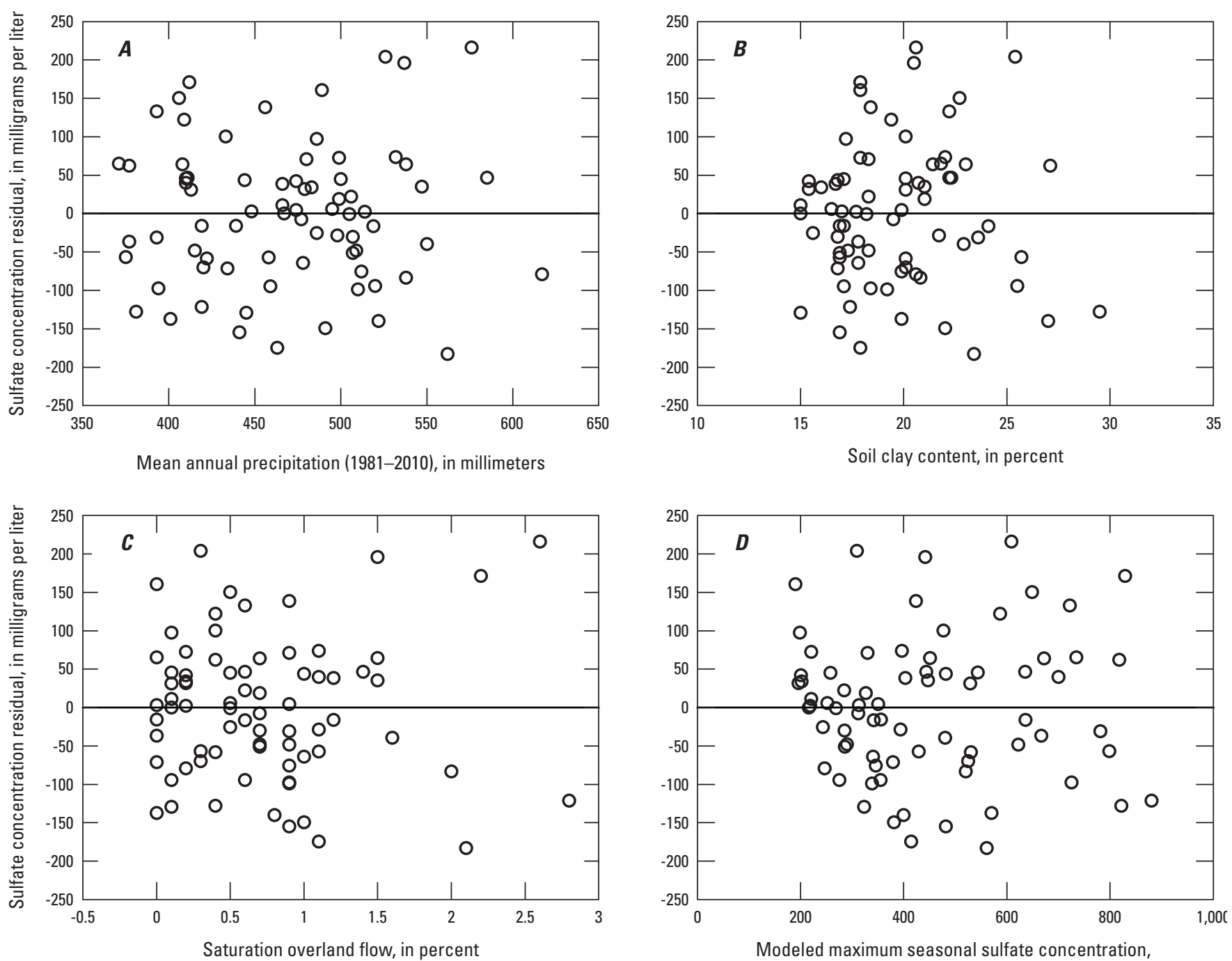
in milligrams per liter
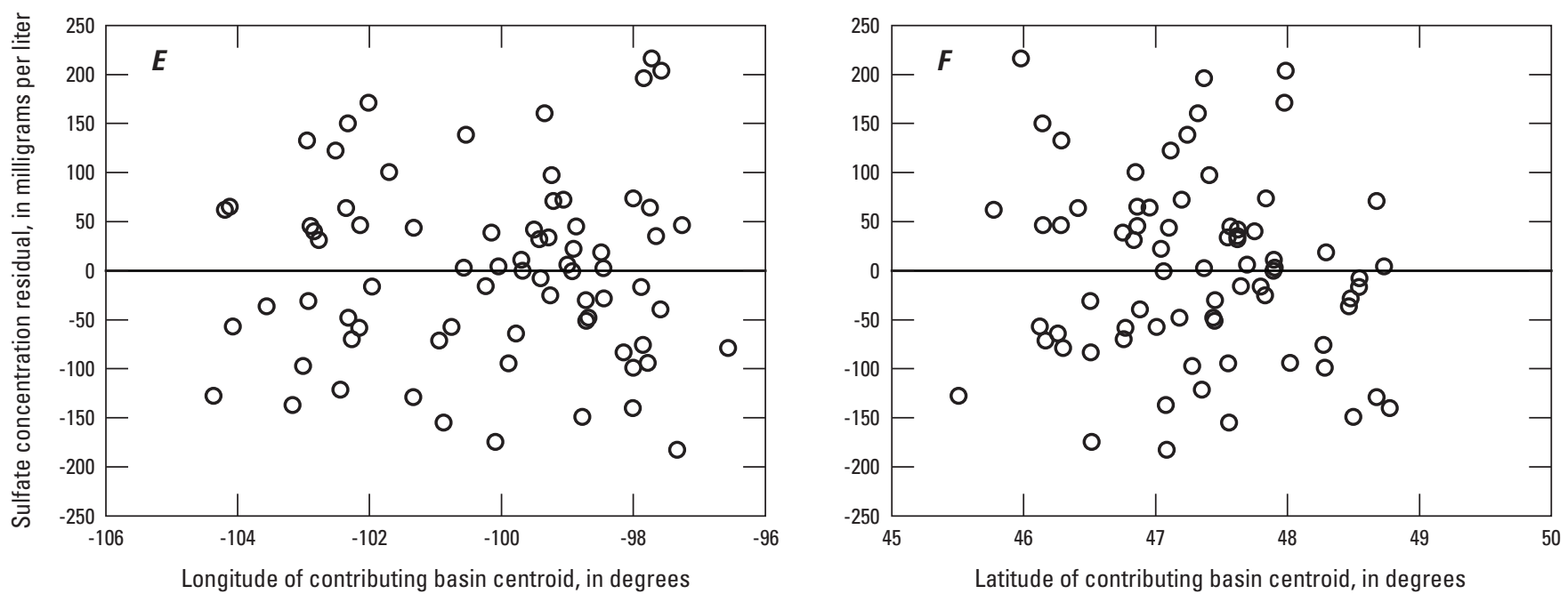

Figure 7. Comparison of sulfate concentration residuals to modeled concentrations and basin characteristics for selected sites in North Dakota. $A$, mean annual precipitation, 1981-2010; $B$, soil clay content; $C$, saturation overland flow; $D$, modeled maximum seasonal sulfate concentration; $E$, longitude of contributing basin centroid; and $F$, latitude of contributing basin centroid. 

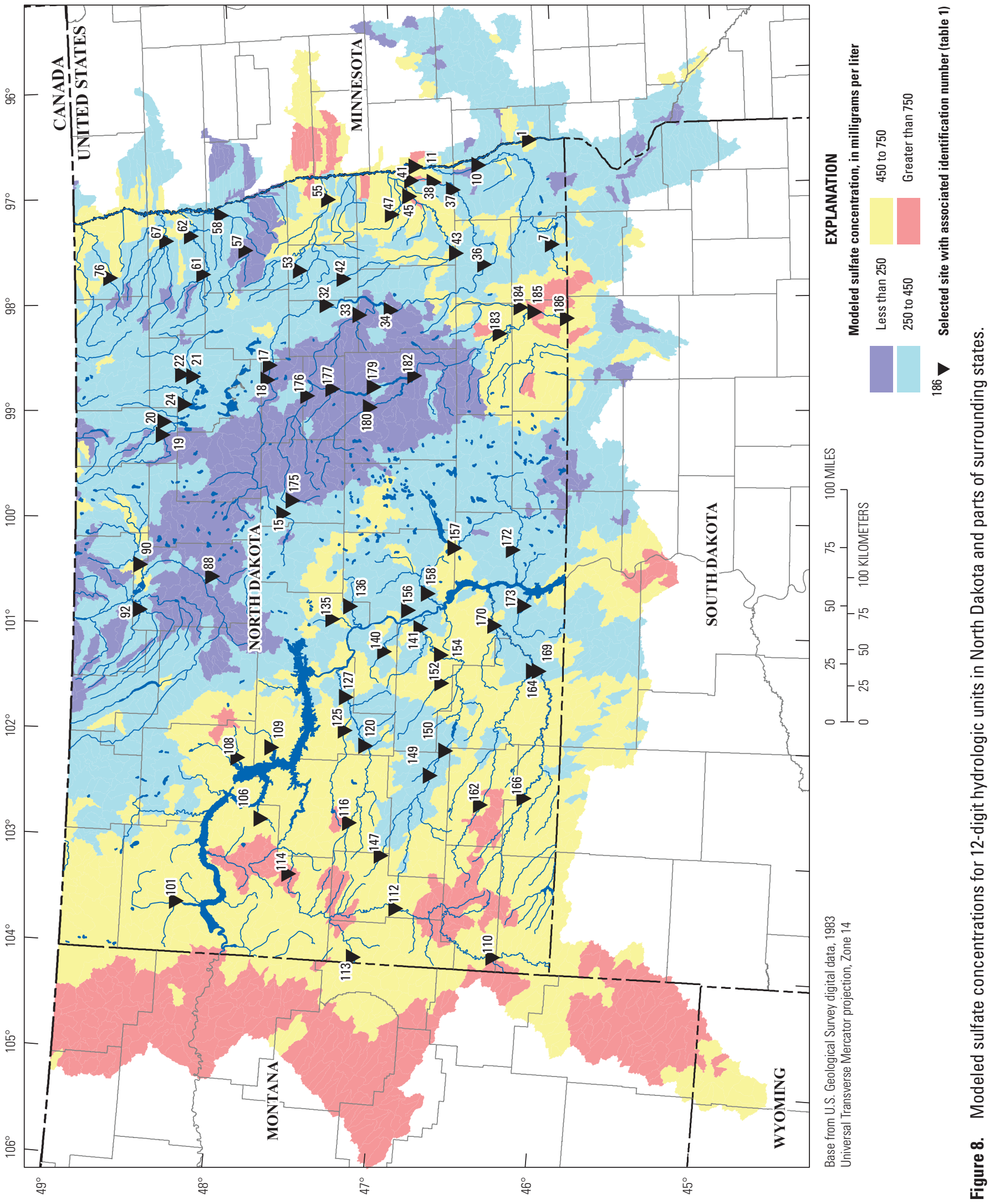


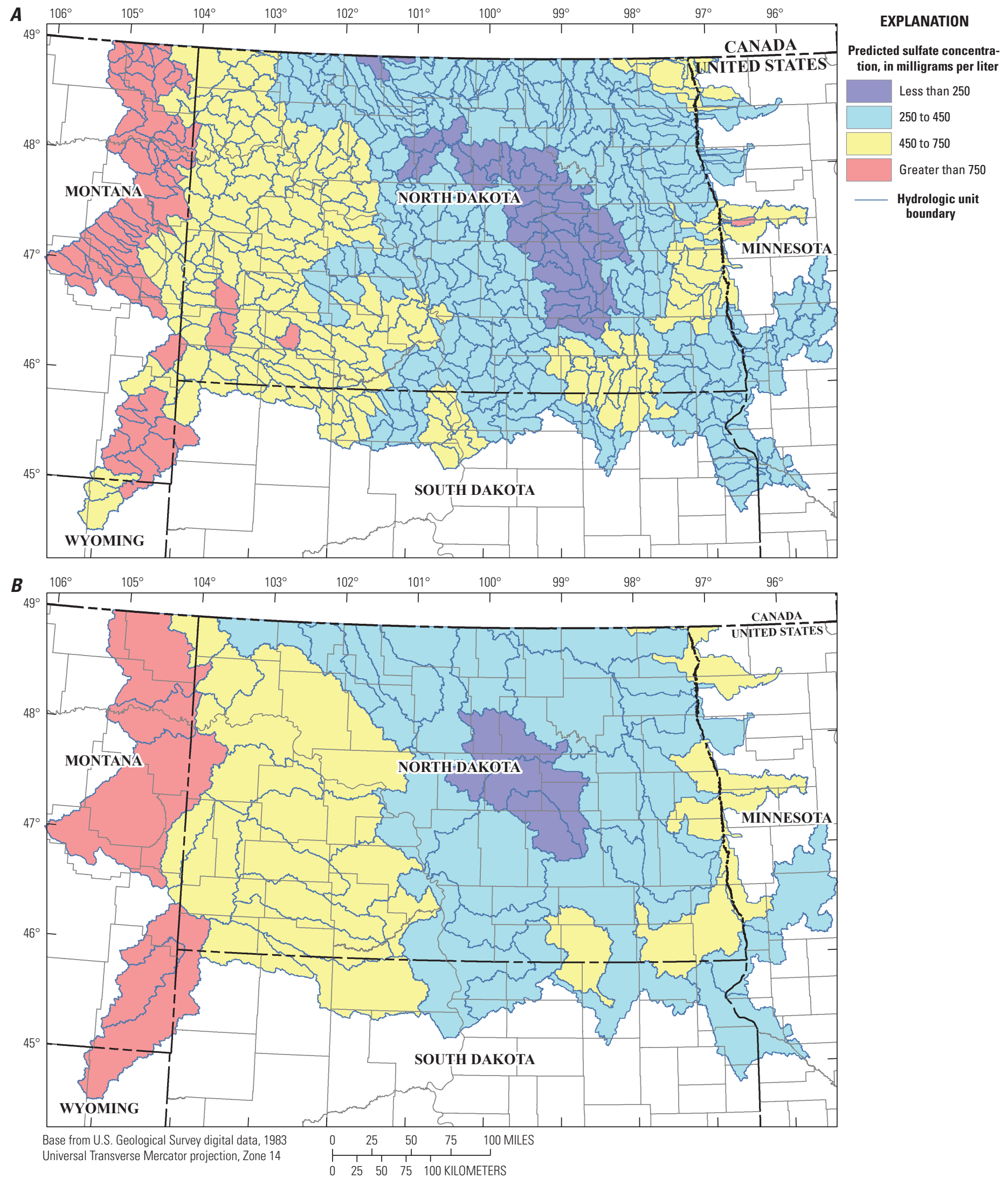

Figure 9. Modeled sulfate concentrations for $A$, 10-digit and B, 8-digit hydrologic units in North Dakota and parts of surrounding states. 
Furthermore, because none of the variables in the regression model were transformed, the modeled sulfate concentration for a particular basin consisting of one or more HU's can be obtained either by using equation 1 directly or by computing a weighted average of the modeled sulfate concentrations for the HU's in the basin. Equation 1 was applied using characteristics extracted for each 12-digit HU to compute modeled sulfate concentrations for North Dakota and surrounding contributing basins (fig. 8). Modeled sulfate concentrations generally were highest (greater than $750 \mathrm{mg} / \mathrm{L}$ ) in HUs in eastern Montana and western North Dakota and lowest (less than $250 \mathrm{mg} / \mathrm{L}$ ) in HUs contributing to the upper Sheyenne River and upper James River (figs. 1, 2, and 8). HUs contributing to the James River and Sheyenne River were unique in that although the lowest modeled sulfate concentrations in North Dakota were observed in the upper James and Sheyenne Rivers (less than $250 \mathrm{mg} / \mathrm{L})$ some of the higher values $(450-750 \mathrm{mg} / \mathrm{L})$ were observed in HUs in the lower James and Sheyenne Rivers. Most of the difference in modeled sulfate concentrations in the James and Sheyenne River Basins was because of the low SOF and SCC in the upper basins and the high SOF and SCC in the lower basins (fig. 5). Area-weighted means for the modeled sulfate concentrations also were computed for 10-digit and 8-digit HUs for streams in North Dakota and surrounding contributing basins (fig. 9). The resulting distribution of modeled sulfate concentrations was similar to the distribution for the 12-digit HUs (fig. 8), but less variable because the basin characteristics were averaged over larger areas.

\section{Summary}

Recent analyses of water-quality data collected from North Dakota's streams indicated trends of increasing sulfate concentrations across the State. Water-quality analysis by the North Dakota Department of Health also indicated that the sulfate standards for various stream classifications, which are based on 30-day moving average sulfate concentration, have been exceeded at a number of stream water-quality monitoring locations across the State, some by an order of magnitude. Previous studies have indicated that the increasing sulfate concentrations probably were caused by generally wetter conditions and resulting increases in contributing drainage areas and water tables beginning about 1993. The increasing sulfate across the State has prompted questions about whether the State's current stream classification system, which includes the sulfate concentration standards, still appropriately reflects natural conditions. Where natural conditions cause exceedances of the existing sulfate standards, the North Dakota Department of Health may consider changes to the classification status of certain streams to reflect the higher sulfate concentrations.

A study was conducted by the U.S. Geological Survey in cooperation with the North Dakota Department of Health and the North Dakota State Water Commission to evaluate the relation of maximum seasonal (30-day moving average) sulfate concentrations at monitoring sites to characteristics of the contributing basins in North Dakota to model the expected naturally-occurring sulfate concentrations in streams.

A spatial analysis was conducted with digital data using a Geographic Information System to obtain selected basin characteristics for each 12-digit hydrologic unit associated with North Dakota streams. Characteristics used in the regression analysis extracted for each hydrologic unit included the mean annual precipitation (1981-2010), mean percent soil clay content, and mean percent saturation overland flow. For the regression analysis, a single value for each characteristic was needed for each of 75 stream sampling sites that had associated sulfate data during 1993-2008. For each site, all of the 12-digit hydrologic units upstream from the site were combined and an area-weighted mean based on the area of each 12-digit hydrologic unit was computed for the mean annual precipitation, percent soil clay content, and percent saturation overland flow for the basin upstream from the site.

Many of the sites used in this study were sampled as part of the North Dakota State Water Commission High-Low sampling program, and were sampled two times per year (once during high-flow conditions and once during low-flow conditions). These sites did not have enough data to estimate the maximum seasonal sulfate concentration. However, 28 sites had sufficient sampling frequencies to estimate the maximum seasonal sulfate concentration, and for those sites it was determined that the 75 th percentile of the high-low samples was a good estimate of the maximum seasonal sulfate concentration. Therefore, to allow for consistent estimation of the maximum seasonal concentration for the selected 75 sites, including the High-Low Sampling Program sites, the 75th percentiles of the High-Low Sampling Program samples were computed and used to estimate the maximum seasonal sulfate concentrations. To simulate High-Low Sampling Program sampling for sites that had higher sampling frequencies in each year, only the concentration samples nearest to April 15 (high flow) and August 15 (low flow) were selected. The modeled sulfate concentration was obtained using ordinary least-squares regression with the 75th percentile of the selected High-Low Sampling Program samples as the dependent variable and the three spatial variables as the explanatory variables.

The regression results indicated that modeled sulfate concentration increased by 146.7 milligrams per liter per 1-percent increase in saturation overland flow, 11.4 milligrams per liter per 1-percent increase in soil clay content, and 4.7 milligrams per liter per 1 millimeter decrease in mean annual precipitation for mean annual precipitation below 475 millimeters. For mean annual precipitation greater than 475 millimeters (covering about the eastern 1/3 of the State), modeled sulfate concentration did not vary with mean annual precipitation. Each of the coefficients for the explanatory variables was highly significant ( $p$-values less than 0.001 ) and the direction of the relations between modeled sulfate concentration and each of the explanatory variables was consistent with physical expectations. Because none of the variables 
in the regression model were transformed, modeled sulfate concentration for a particular basin consisting of one or more hydrologic units was equivalent to the weighted average of the modeled sulfate concentrations for each of the hydrologic units in the basin.

Modeled sulfate concentrations generally were highest (greater than 750 milligrams per liter) for basins in western North Dakota and lowest (less than 250 milligrams per liter) for basins in the upper Sheyenne River and upper James River. Area-weighted means for the basin characteristics also were computed for 10-digit and 8-digit hydrologic units for streams in North Dakota and sulfate concentrations were estimated from the characteristics. The resulting distribution of modeled sulfate concentrations was similar to the distribution of estimates for the 12-digit hydrologic units, but less variable because the basin characteristics were averaged over larger areas.

\section{References Cited}

Beven, K.J., and Kirkby, M.J., 1979, A physically based, variable contributing area model of basin hydrology: Hydrological Sciences Bulletin, v. 24, p. 43-69.

Franzen, D., 2007, Managing saline soils in North Dakota: North Dakota State University Extension Service SF-1087 (revised), $12 \mathrm{p}$.

Galloway, J.M., Vecchia, A.V., Vining, K.C., Densmore, B.K., and Lundgren, R.F., 2012, Evaluation of water-quality characteristics and sampling design for streams in North Dakota, 1970-2008: U.S. Geological Survey Scientific Investigations Report 2012-5216, 304 p.

Helsel, D.R., and Hirsch, R.M., 1995, Statistical methods in water resources: New York, Elsevier Science B.V., 529 p.

Hem, J.D., 1985, Study and interpretation of the chemical characteristics of natural water: U.S. Geological Survey Water-Supply Paper 2254, 263 p.

Hoerling, M., Eischeid, J., Easterling, D., Peterson, T., and Webb, R., 2010, Understanding and explaining hydroclimatic variations at Devils Lake: National Oceanic and Atmospheric Administration, Climate Assessment Report, $20 \mathrm{p}$.

North Dakota Department of Health, 2010, Standards of Water Quality for the State of North Dakota: Bismarck, North Dakota, North Dakota Department of Health, Division of Water Quality, accessed March 11, 2012, at http://www. legis.nd.gov/information/acdata/pdf/33-16-02.1.pdf.

PRISM Climate Group, 2012, PRISM Products Matrix: accessed February 21, 2013, at http://www.prism. oregonstate.edu/products/matrix.phtml.
Rehm, G., 2002, The value of gypsum: University of Minnesota Extension, Minnesota Crop eNews, accessed May 21, 2013, at http://www.extension.umn.edu/ cropenews/2002/02MNCN07.htm.

Schuh, W.M., and Hove, M.H., 2006, Sources and processes affecting dissolved sulfate concentrations in the Upper Sheyenne River: North Dakota State Water Commission Technical Report, 53 p.

TIBCO Software Inc., 2010, TIBCO Spotfire S+: Somerville, Mass., accessed January 4, 2008, at http://spotfire.tibco. $\mathrm{com} /$ products/s-plus/statistical-analysis-software.aspx.

Wolock, D.M., 2003a, Infiltration-excess overland flow estimated by TOPMODEL for the conterminous United States: U.S. Geological Survey Open-File Report 03-310, digital dataset. [Also available at http://water.usgs.gov/lookup/ getspatial?ieof48.]

Wolock, D.M., 2003b, Saturation overland flow estimated by TOPMODEL for the conterminous United States: U.S. Geological Survey Open-File Report 03-264, digital dataset. [Also available at http://water.usgs.gov/lookup/ getspatial?satof48.]

U.S. Department of Agriculture, 2006, Digital general soil map of U.S.: U.S. Department of Agriculture, Natural Resources Conservation Service, accessed February 21, 2013, at http://soildatamart.nrcs.usda.gov/Metadata. aspx? Survey $=U S$.

U.S. Geological Survey, 2013, Annual water data reports: accessed March 15, 2013, at http://wdr.water.usgs.gov/.

U.S. Geological Survey, U.S. Department of Agriculture, and Natural Resources Conservation Service, 2012, Federal Standards and Procedures for the National Watershed Boundary Dataset (WBD) (3rd ed.): U.S. Geological Survey Techniques and Methods book 11, chap. A3, 63 p.

Vecchia, A.V., 2003, Water-quality trend analysis and sampling design for streams in North Dakota, 1971-2000: U.S. Geological Survey Water-Resources Investigations Report 03-4094, 73 p.

Vecchia, A.V., 2005, Water-quality trend analysis and sampling design for streams in the Red River of the North Basin, Minnesota, North Dakota, and South Dakota, 1970-2001: U.S. Geological Survey Scientific Investigations Report 2005-5224, $54 \mathrm{p}$.

Vecchia, A.V., 2008, Climate simulation and flood risk analysis for 2008-40 for Devils Lake, North Dakota: U.S. Geological Survey Scientific Investigations Report 2008-5011, $28 \mathrm{p}$. 
Publishing support provided by:

Rolla Publishing Service Center

For more information concerning this publication, contact: Director, USGS North Dakota Water Science Center

821 East Interstate Avenue

Bismarck, North Dakota 58503

(701) 250-7400

Or visit the North Dakota Water Science Center Web site at: http://nd.water.usgs.gov/ 
